\title{
How Courts Interpret Regulations
}

\section{Frank C. Nereman*}

A REPUBLICAN CONGRESSMAN, reviewing his party's achievements and directives from Washington has "dwindled to a tiny trickle"." If true, this news might be welcomed by many citizens. The facts, though, suggest that the Congressman was misinformed. Republican or Democratic, governing seems to require a constant use of rulemaking powers by administrators. The wartime peak is passed, of course; but during the first ten months of 1947 our administrative lawmakers published more than 7,000 pages of material in the Federal Register (three columns to the page). And loose-leaf editors, trade associations, and other compilers of government's printed products seem burdened, still, with the same bulk of press releases, pamphlets, and comparable items that has accompanied the peacetime $F$ ederal Register since its New Deal inception."

The regulations of federal agencies have accumulated to such an extent that they now parallel the Statutes at Large in coverage and significance. They are like statutes, too, because they are general rules stating in fixed terms the legal consequences that follow operative facts. ${ }^{3}$ Seeing this likeness, lawyers have often treated regnlations as

* Lecturer in Law, University of California.

1 Representative E. Mundt (S. Dak.), as reported in an Associated Press dispatch from Washington dated April 13, 1947.

2 See Martin, Someone Asked Them to Do It-Cutting the Government's costly informational setup isn't easy [April 1947] 35 NaTron's BusINEss (No.4) 40; Sullivan, Governnrent by Minzeograph (1938) 161 AIz. MONTHLx 306; cf. (1942) 35 LAw LxB. J. 302 ("If anybody wanted to have a complete document collection today of just federal material alone, he would have to hire a warehouse.").

${ }^{8}$ This article embraces all kinds of administrative regulations ("Iegislative" and "interpretive", formal and informal, etc.). Cf. $\$ 2$ (c) of the Administrative Procedure Act, Pub. L. No. 404, 79th Cong. 2d Sess. (June 11, 1946), 5 U. S. C. A. (1946) § 1001 (c); infra note 205. Rules of the Court of Claims, the Customs Court, and the Tax Court are not considered, however, simce the precedents which govern their interpretation involve procedural rules of courts rather than administrative regulations. E.g., see International Banding Mach. Co. v. Com'r of Internal Revenue (C. C. A. 2d, 1930) 37 F. (2d) 660; cf. Com'r v. Estate of Bedford (1945) 325 U.S. 283, 287; National Labor Relations Board v. J. S. Popper, Inc. (C. C. A. 3d, 1940) 113 F. (2d) 602, 603; Note (1947) 33 A.B. A. J. 950 . Nor does the article deal with interpretive problems concerning standardform government contracts (cf. Hust v. Moore-McCormack Lines (1946) 328 U. S. 70\%), private documents approved by government agencies (compare Illinois Steel Co. v. Baltimore \& O. R. Co. (1944) 320 U. S. 508, with Atchison, T. \& S. F. Ry. Co. v. Guthrie 
statutes, particularly when interpretive questions arise. ${ }^{4}$ This article, dealing with the interpretation of regulations, notes the statutory analogies but suggests that there are differences, as well, which call for special study.

Regulations need interpretation because they do not always regulate clearly. People affected by them, like people affected by statutes, are often unable to find out what the language means. At times, the words seem senseless-as in this remarkable quotation:

All commodities histed in Appendix A are those known to the trade as such excepting therefrom such thereof, if any, while subject to another regulation. ${ }^{5}$

Often, the words are too legalistic - as in this find of the New Yorker editors:

The respective resulting amounts in each class shall be known as the "net pooled Class I skim milk", "net pooled Class I butterfat", "net pooled Class II skim milk", "net pooled Class II butterfat", "net pooled Class III skim milk", and "net pooled Class III butterfat"; the sum of the "net pooled Class I skim milk", "net pooled Class II skim milk", and "net pooled Class III skim milk" shall be known as the "net pooled skim milk" and the sum of the "net pooled Class I butterfat", "net pooled Class II butterfat", and "net pooled Class III butterfat" shall be known as the "net pooled butterfat".。

Cotton Oil Co. (C. C.A.10th, 1943) 139 F. (2d) 10), orders of individual application (cf. Crescent Express Lines v. U.S. (1943) 320 U.S. 401), or findings (cf. Levinson v. Spector Motor Service (1947) 330 U.S. 649, 694, n. 16).

4 E.g., see Schafer v. Felvering (1936) 299 U.S. 171, 172; Montague v. U.S. (1934) 79 Ct. Cl. 624, 629; 2 Sutherdand, Statutes and Statutory Construction (3d ed. 1943) 280.

5 (1943) 8 FED. REg. 10559, quoted also in Second Intermediate Report of the Select Comnittee to Investigate Executive Agencies (1943) H. R. REP. No. 862, 78th Cong. 1st Sess., at 8, n. 32. In a mimeographed Statement in Answer to this report, the OPA coininented, "[the quotation was] . . . a badly-drafted definition . . . applying to fruitcake which was so exceptional that it had been singled out for newspaper ridicule months before the Committee chose to publish it anew. Actually, no other agency has gone as far as OPA in simplifying the form and style of its regulations." (p. 8.) Cf. Bowles v. Eastern Sugar Associates (D. Md. 1946) 64 Fed. Supp. 509, 513 (" . . the draftsmanship ... . is inexcusably poor and creates a situation which is calculated to befuddle even the most astute legal mind, not to speak of the general public . . .."); and see Strayer, Why Must OPA Irritate You?, in the Washington Daily News, Jan. 9, 1943, at 17.

In Nichols v. Sylvester Co. (C. C. A. Ist, 1926) I6 F. (2d) 98, 99, a tax case, the court concludes that the first two sentences of a Treasury regulation are irreconcilable and that even if they could be reconciled the document as a whole would be inconsistent with another Treasury regulation.

' From the WFA Milk Marketing Order for New Orleans, 7 Code Fed. Reas. (Supp. 1945) §942.4(e) (9); quoted also in THe New YoRker, March 3, 1945, at 75 ("Let's just sell the cow."). In Marlene Linens v. Bowles (Em. Ct. 1944) 144 F. (2d) 874, 876, 
The doubt in most regulations, however, is caused not by draftsmen who are illiterate or tone-deaf but by draftsmen who are uninformed, unimaginative, or uncertain. For various reasons, they may fail to foresee problems. (In Maximum Price Regulation 220, for example, language desigued to cover "rubber commodities" such as tires, tubes, and typewriter feet was later construed to apply also to bathing suits, brassieres, and dress shields. ${ }^{7}$ ) Or, when they do foresee a problem, they may choose not to set the answer. (A recent ICC regulation defines "loaders" as men devoting "a large part" of their time to activities that affect safety..$^{8}$ ) To be contrasted are instances where a zeal to foresee and provide for problems has made the authors too perspicacious. (In the tax field, for example, loopholes have been plugged and aberrational problems solved so often that many of the documents are monstrosities. ${ }^{9}$ )

Further, even when regulations are neither too vague nor too specific, they may perplex because they lack synthesis. In the early months of price control, retail grocers were expected to know the requirements of not only the GMPR (an over-all regulation) but also

the court admitted that an agency can legally concoct a definition which does not conform "to common usage, or to dictionary precision, or to the understanding of the trade". Cf. Conard, New Ways to Write Laws (1947) 56 YALE L. J. 458; Flescr, THe ART of PIATN TALK (1946) c. XIX ("How to Read the Federal Register").

7 The interpretation was restated, formally, in Appendix A of Amendment No. 2 (1942) 7 FED. REG. 11111; of. the text as first issued, (1942) 7 FED. REG. 7282. By including in the regulation "any commodity made in whole or in part of rubber", the authors (OPA's Rubber Products Branch) umintentionaily affected industries wholly outside their authority. Cf. Pearson v. Walling (C. C. A. 8 th, 1943) 138 F. (2d) 655 (manufacturers of bows and arrows held subject to regulation governing "The Lumber and Timber Products Industry").

8 See Levinson v. Spector Motor Service (1947) 330 U.S. 649, 670 ("While the indefiniteness of the terms 'large' or 'substantial' is obvious, nevertheless, those are the words which the Commission has chosen to use in dealing with this subject."). Cf. Elhart, Operating in a Fogl, in the Women's Wear Daily, Jan. 6, 1943, at 35.

${ }^{9}$ See Lasser, A Plea for the Small Taxpayer (April 1947) TAx OuTLoox 12 ("... our income tax forms are a phantasmagoria of exemptions, deductions, graduated surtax brackets, computations of capital gains and losses, percentages piled on nets and all those other minutiae."). In 1944, when "pay-as-you-go" and "forgiveness" were previewed by some fifteen million taxpayers, THE NEW YORKER pleaded: 'Let's not only forgive, let's forget!" (March 11, 1944, at p. 7.) And see Tax Addled, Brother? READ ON!, in the Washington Daily News of Feb. 14, 1944 ("Six News reporters were given identical income figures and assigned to get a blank worked out by Government experts. They got six different results."). The Washington Post reported that on the final day 15,472 persons passed through the local collector's office. (March 16,1944.) Even on the preceding day, "A continuous stream of some 1500 persons leaned against the walls or sat on the floor of the Internal Revenue Building .... and newcomers were directed to walk several blocks through the building to find the line's end." (March 15, 1944.) 
a whole series of special regulations, each creating ceilings for items such as soups, canned vegetables, jams and jellies, dried fruits, and "miscellaneous products". ${ }^{10}$ Other retailers (department stores, for example) were faced with more than fifty regulations fixing prices for consumer goods. Some were dollars-and-cents prices. Others depended upon sums paid the supplier. Still others depended upon each retailer's own practices. Base periods differed. Methods of computation differed. Classifications and definitions differed. The result, for thousands of normally law-abiding citizens, was chaos. ${ }^{11}$

Whatever the cause, questions of meaning will lurk in regulations as in all documents. ${ }^{12}$ The grocer, the shop steward, the government official, the attorney, and every other person concerned with regulations will find in them ambiguities of varying complexity. In the pages which follow, we shall consider ambiguities that have raised legal issues. We shall outline, for regulations, a few of the interpretive difficulties that have often been outlined for statutes, contracts, and other legal writings. ${ }^{13}$ The aim is to explore techniques judges have

10 See Dickerson, FPR No. 1, An Experiment in Standardized and Prefabricated Law (1945) 13 U. of CHI. L. REv. 90, 91.

${ }^{11}$ See Elhart, Is Retail Price Control Mechanism Workable? in the Women's Wear Daily, Dec. 16, 1942, at 1; cf. Hecht Co. v. Bowles (1944) 321 U.S. 321, 325 ; Bowles v. Co-operative G. L. F. Farm Products (W. D. N.Y. 1943) 53 Fed. Supp. 413,416 ("Regulation 333 ... includes a total of sixty finely printed pages. It is to be little wondered that confusion might arise in the construction of the meaning of soune provisions."). There were some reforms, eventually. See MPR 580 (1945) 10 FED. REc. 3015, and Dickerson, op. cit. supra note 10. But cf. Diven v. Porter (C. C. A. 8th, 1946) 157 F. (2d) 593; and Hardware Dealers Want OPA Relief, in the Washington Post of Mar. 29, 1946 ("Builders' bardware representatives ... plan to appeal to OPA ... for a revision of fifteen or twenty regulations covering their sales."). And see United Public Workers v. Mitchell (1947) 330 U.S. 75, 110 (" . . . what federal employees can or cannot do, consistently with the various civil service regulations, rules, warnings, etc., is a matter of so great uncertainty that no person can even make an intelligent guess."). As to comparable problems in England, see Note (1943) 93 L. J. 222, 223.

12 Cf. Nutting, The Ambiguity of Unambiguous Statutes (1940) 24 MnNN. L. REv. 509; Commissioner of Internal Rev. v. Shamberg's Estate (C. C.A. 2d, 1944) 144 F. (2d) 998, 1006, n. I ("Too frequently lawyers blame the difficulties of statutory interpretation on the incptitude of the legislature.").

13 Cf. Powell, Construction of Written Instruments (1939) 14 IND. L. J. 309, 311 ("Ten or twenty years hence and perhaps long before that time, you may well need an Institute dealing with the construction of the rules of admimistrative bodies."). The literature on interpretation of regulations is notably sparse. Less than two pages were allotted in Professor Horack's 3-volume treatise (SuTBERIAND, op. cit. supra note 4, at 279), and only six lines (plus citations) in the Commerce Clearing House handbook (CCH, Fed. Ad. Proc. (1944) II 2275; cf. ibid. (2d ed. 1946) \1323). For additional references see Vom Batr, Federar Adminsstrattve. Law (1942) 442; (1942) 42 AM. J.UR. 431 (no citations in pocket part, however). Cf. KATZ, CASES AND MA- 
developed for resolving those difficulties. Judges' opinions are emphasized, not because they are more correct or socially significant than, say, the opinions of government officials or Wall Street lawyers, but because they are authoritative. Since they are authoritative, government officials, Wall Street lawyers and anyone else who would acquire expertness in this field must know their framework and their logic. In analyzing the opinions, we shall discuss first the Supreme Court cases and then those from the lower courts. The closing pages will deal with the "rule of deference", to which judges often refer, and will pose problems iniplicit in that rule which as yet remain unsolved.

\section{SUPREME COURT CASES}

The Suprenie Court has decided hundreds of cases which relate to regulations. In most, the dispute has involved only validity; ${ }^{14}$ or words of a regulation were quoted merely to justify some other noninterpretive holding. ${ }^{15}$ Even when a question of neaning has been stated, the Court niay accept a litigant's interpretation and, nevertheless, rule against him because of related issues. ${ }^{16}$ On occasion, the supposed interpretive issue may be treated as a question of fact, ${ }^{17}$ or as requiring not the interpretation of a regulation but the interpretation of a statute ${ }^{18}$ or the Constitution. ${ }^{19}$ In none of these cases, of course,

TERIAIS ON ADAINISTRATIVE LAW (1947) 312 (contains section subtitled "Interpretation by Administrative Agency of Its Own Rules"); GeLrHORN, ADMrnistrative LAwCases and Comments (2d ed. 1947) 1002 (contains excerpts froin Seminole case, infra note 73); McFariand and Vanderbitt, Cases on Adartnistrative Law (1947) 106 (reprints relevant Texas case and cross-references Addison v. Holly Hill Co., infra note 74). The only other general discussion of the subject seems to be in chapter 5 of LIEBER on ReGutations (1898). There are, however, analyses of particular kinds of regulationg. E.g., Littauer, The Unfreezing of Foreign Funds (1945) 45 Cor. L. Rev. 132, 134; Notes, Validity, construction, and application of probationary provisions of civil service statutes or regulations (1941) 131 A.L.R. 383; Construction and application of regulations as to milk (1939) 122 A. L. R. 1062; Samuels, The Essential Work Order-Some Points or Construction (1945) 95 L. J. 291.

"14 See 1 Vom Bator, Federal Admmnistrative Law (1942) 486; cf. Umited States v. Anderson (1946) 328 U.S. 699, 704, n. 10. But agreement by litigants as to the meaning of a regulation does not foreclose independent analysis by the Court. Gibson v. United States (1946) 329 U. S. 338, 344, n. 9 ; cf. A. T. \& T. Co. v. United States (1936) 299 U.S. 232,241 ("We accept this declaration as an administrative construction binding upon the Coumission in its future dealings with the companies.").

15 E.g., Cosmos Co. v. Gray Eagle Co. (1903) 190 U.S. 301, 313.

16 E.g., Tucker v. Texas (1946) 326 U.S. 517, 519; State of Georgia v. Pennsylvania R. Co. (1945) 324 U.S. 439, 459, n. 7.

17 E.g., Walling v. General Industries Co. (1947) 330 U. S. 545.

18 E.g., Hulbert v. Twin Falls County (1946) 327 U.S. 103. And see United States v. Silk (1947) 331 U.S. 704, 715; Bartels v. Birmingham (1947) 332 U.S. 126, 131 ;

10 See page 514. 
do the opinions tell us how the Court interprets regulations. Nor do opinions where an interpretive argument was iguored ${ }^{20}$ or denounced as specious, ${ }^{21}$ or where the Court, while acknowledging ambiguity, gave no reason for its choice of one interpretation rather than another. ${ }^{22}$

The opinions which are informative are those where members of the Court have puzzled with the meaning of a regulation as a major issue in the case. The recent Ute Indians case is an example. ${ }^{23}$ There, a regulation providing for the Utes' use of lands adjoining their reservation had been issued by President Grant, yet its legal effect had never been determined. Justice Black, speaking for the Court, concluded that neither Grant nor any of his subordinates had intended to give the Indians any more than a possessory interest in the lands. Justices Murphy, Frankfurter, and Douglas, dissenting, argued that this conclusion disregarded the "plain words" of the regulation.

Do this case and similar cases suggest. rules for resolving interpretive doubts as to regulations? The conflict there illustrated, requiring choice between "intent" and "plain words", seems to vex our interpretations of all writings. Judges and scholars have not yet rationalized that conflict in allied fields, ${ }^{24}$ and they are not likely to be more

cf. Burnet v. Chicago Portrait Co. (1932) 285 U.S. 1, 16 (" . . ambiguous regulations are of little value in resolving statutory ambiguities.").

${ }^{19}$ See the concurring opinions of Justices Murphy and Roberts in Ex parte Endo (1944) 323 U.S. 283, 307, 308.

20 E.g., Belden v. Chase (1893) 150 U.S. 674.

21 Addison v. Holly Hill Co. (1944) 322 U.S. 607, 610, n. 1 ("a plain solecism"); Robinette v. Helvering (1943) 318 U.S. 184, 188 ("It is impossible to conceive of this as even approaching a transaction 'in the ordinary course of business." "). And see Garrison v. United States (1868) 74 U.S. (7 Wall.) 688, 691.

22 E.g., Bartchy v. United States (1943) 319 U.S. 484, 488; Guggenhein v. Rasquin (1941) 312 U.S. 254, 258.

23 Ute Indians v. United States (1947) 330 U.S. 169.

$2 t$ Cf. Choctaw Nation v. U.S. (1943) 318 U.S. 423 (plain words of Indian treaty held controlling regardless of findings as to intent of parties). On the issue of plain words versus intent, Brown Lumber Co. v. L. \& N. R. Co. (1937) 299 U.S. 393 and Ilinois Central Railroad v. McKendree (1906) 203 U.S. 514 seem contra to the Ute Indians case. Cf. Frankfurter, Some Reflections on the Reading of Statutes (1947) 47 Cor. L. REv. 527, 529 ("I should say that the troublesome phase of construction is the determination of the extent to which extraneous documentation and external circumstances may be allowed to infiltrate the text on the theory that they were part of it, written in ink discernible to the judicial eye.") ; Nutting, The Relevance of Legislative Intention Established by Extrinsic Evidence (1940) 20 B.U.L. REv. 601; 3 WILLISTON, Contracts (Rev. ed. 1936) §610; RestatemenN, Property (1940) \$242. Also cf. the type of problem illustrated by Levers v. Anderson (1945) 326 U.S. 219, 223 (Is the word "may" mandatory or directory?). 
successful here. That conflict is not, however, our sole concern in reading documents. Interpretive doubts as to regulations raise varied questions, and the following paragraphs deal with some of those questions in detail.

\section{Extrinsic aids}

Fortunately, the regulations cases seem to be free from any doctrine akin to the parol evidence or plain meaning rules. Hence, the Court does not pervert its analysis of regulations by refusing to examine relevant facts. ${ }^{25}$ In the Ute Indians case, the dissenters did not contest the majority's reference to administrative interpretations of Grant's regulation, as shown by correspondence between an Indian Agent and the Commissioner of Indian Affairs. Their sole contention was that such evidence, though admissible, did not justify disregard of the explicit words. In other cases, without preparatory findings as to ambiguity, the Court has weighed the relevance of extrinsic aids such as prior, ${ }^{20}$ contemporaneous, ${ }^{2 \pi}$ and subsequent ${ }^{28}$ regulations of the agency, as well as interpretations shown by its report to Congress, ${ }^{29}$ memorandums of its solicitor ${ }^{30}$ and general counsel, ${ }^{31}$ an "office decision", 32 a popularized brochure, ${ }^{33}$ a press release, ${ }^{34}$ a telegraphic order ${ }^{35}$ the testimony of a chief accountant, ${ }^{36}$ a statement by the assistant attorney general appearing for the agency, ${ }^{37}$ adjudications ${ }^{38}$

25 Cf. McBaine, The Rule Against Disturbing Plain Meaning of [Private] Writings (1943) 31 CALIF. L. REv. 145; Jones, The Plain Mreaning Rule and Extrinsic Aids in the Interpretation of Federal Statutes (1939) 25 WASH. U.L.Q. 2.

$2 \varepsilon$ Gibson v. United States (1946) 329 U. S. 338, 344; Spreckels v. Commissioner (1942) 315 U.S. 626, 629.

27 Patterson v. Lamb (1947) 329 U.S. 539, 542; Kraus \& Bros. v. United States (1946) 327 U.S. 614, 625.

23 Billings v.' Truesdell (1944) 321 U.S. 542, 554; Penn Dairies v. Milk Control Comm'n (1943) 318 U.S. 261, 276; Addy Co. v. United States (1924) 264 U. S. 239, 245.

29 Bowles v. Seminole Rock Co. (1945) 325 U.S. $410,417$.

30 U. S. v. Safety Car Heating Co. (1936) 297 U. S. 88, 95.

31 Spreckels v. Commissioner (1942) 315 U.S. 626, 629, n. 9.

32 U.S. v. Safety Car Heating Co., supra note 30.

33 Bowles v. Seminole Rock Co., supra note 29.

34 Ex parte Kawato (1942) 317 U.S. 69, 77, n. 13.

35 Patterson v. Lamb (1947) 329 U.S. 539, 544.

36 A. T. \&. T. Co. v. United States (1936) 299 U. S. 232, 240.

35 Ibid. at 239 .

38 Brown Lumber Co. v. L. \& N. R. Co. (1937) 299 U. S. 393, 399; United States v. Eaton (1898) 169 U.S. 331, 342. 
the opinion accompanying an adjudication, ${ }^{30}$ reports accompanying rule-making, ${ }^{40}$ and "administrative practice". 41

\section{The maxims}

Though no plain meaning rule shields the Court from its own curiosity, we do find in regulations cases an errant use of other rules borrowed from nonregulations materials. To illustrate: regulations creating crimes have been strictly construed; ${ }^{42}$ regulations governing conduct have been presumed to be without retroactive effect; ${ }^{43}$ regulations of doubtful constitutionality have been limited to what is admittedly constitutional;" and regulations not meeting "a high standard of certainty" have been held not to supersede local law. ${ }^{40}$ As rules of thumb, the maxims supporting such conclusions may not be objectionable. ${ }^{46}$ If, however, they are used to circumvent the real intent of a regulation, the same difficulties will arise as so often arise in cases dealing with statutes. In Addy Co. $v$. United States, ${ }^{47}$ for example, the Fuel Administrator of World War I directed that contracts made before the date of a certain price regulation be exempted. Coal jobbers who had not contracted to sell their coal, but had contracted to buy it f.o.b. mine, pending sale, took a markup higher than the maximum allowed and were convicted and fined for their overcharges. On appeal, they argued that the Administrator had exempted

39 Bridges v. Wixon (1945) 326 U.S. 166, 174, n. 1.

40 Illinois Commerce Comm'n v. U.S. (1934) 292 U.S. 474, 486.

41 Norwegian Nitrogen Co. v. U.S. (1933) 288 U.S. 294, 324; and see Federal

Comm'n v. Pottsville Broadcasting Co. (1940) 309 U.S. 134, 143, n. 6.

42 Kraus \& Bros. v. United States (1946) 327 U.S. 614, 626.

43 See Miller v. United States (1935) 294 U. S. 435, 439.

44 Ex parte Endo (1944) 323 U.S. 283, 299 (regulation meant to go as far as due process clause permits); if. Ilinois Central Railroad v. McKendree (1906) 203 U. S. 514, 528 (regulation applicable to all commerce held to go farther than commerce clause permits). And see Bridges v. Wixon (1945) 326 U.S. 135, 152 ("The rules are designed to protect the interests of the alien and to afford him due process of law."); United States v. Abilene \& So. Ry. Co. (1924) 265 U. S. 274, 289 (due process and hearsay).

45 See IIl. Cent. R. R. Co. v. Public Utilities Comm. (1918) 245 U.S. 493, 510; cf. Arkansas Comm. v. Chicago, etc. R. R. (1927) 274 U.S. 597, 603.

46 See Lattin, Legal Maxims, and Their Use in Stahutory Interpretations (1937) 26 Geo. L. J. 1 ; Helvering v. Winmill (1938) 305 U.S. 79, 83 (In Treasury regulation governing business-expense deductions, "Special provisions limit the application of those of a broad and general nature ....") ; B. \& O. R. Co. v. U.S. (1938) 304 U.S. 58, 60 (when litigant's interpretation, which ICC has neither adopted nor approved, would invalidate ICC regulation, Court adopts interpretation that makes regulation valid). Cf. Koreinatsu v. United States (1944) 323 U.S. 214, where the Court rejects the prescript of in pari materia but adopts a rationale that seems even more artificial (see Dembitz, Racial Discrimination and the Military Judgment (1944) 45 Cos. L. REv. 175, 199). 47 (1924) 264 U.S. 239. 
not only contracts to sell, but also contracts to buy. The Supreme Court accepted this argument and reversed the conviction, stating:

The order must be construed as criminal statutes are-strictly and without retroactive effect unless clearly indicated .... If it be construed as applying to the sales of coal purchased by petitioners prior to August 23rd [the date of the regulation], we must decide a grave constitutional question, not necessary to consider if another view be accepted. ${ }^{48}$

The first objection to this holding is that the application of price control to inventories does not create a "grave constitutional question". Absent doubt as to constitutionality, the evidence seemed to indicate that the Fuel Administrator did not intend to exempt sales of inventories. As a matter of policy, he might well have concluded that a regulation encumbered by such a broad exemption was worse than no regulation at all. Nevertheless, the Court narrowed its inquiry into these problems of intent and policy and allowed a prejudice against laws that even look retroactive to color its decision. ${ }^{50}$

Further, should regulations that create crimes be construed "as criminal statutes are-strictly"? One answer is that criminal statutes often are not construed strictly. ${ }^{51} \mathrm{~A}$ more basic answer is that the rule of strict construction, in practice, has produced inconsistent and erroneous decisions. ${ }^{52}$ An example of how the rule may affect a decision is the recent $K$ raus case, ${ }^{53}$ which involved a price regulation for wholesalers of poultry. A New York wholesaler, taking advantage of an abnormal Thanksgiving demand, decided to sell turkeys (at the ceiling price) only to those retailers who bought a certain quantity of chicken feet (also at the ceiling price). The regulation did not forbid tie-in agreements as such, but it did forbid evasion of ceiling prices "by any direct or indirect methods, in connection with any ... sale

48 Ibid. at 244.

49 Cf. Mulford v. Smith (1939) 307 U.S. 38, 51 ; Fleming v. Rhodes (1947) 331 U.S. 100, 107 "Immunity from federal regulation is not gained through forehanded contracts.").

${ }^{50}$ Cf. Alabama Power Co. v. Patterson (1931) 224 Ala. 3, 4, 138 So. 421, 422 ("It may be conceded that, generally speaking, orders and rules of public bodies, like acts of the Legislature, are deemed prospective unless a contrary intent appears." [Itahics supplied.]). And see Hawkins and Wállace, Antitrust During National Emergencies-Executive Immnunity (1945) 24 Tex L. Rev. 51, 61; (1938) 12 Tulane L. REv. 469.

51 See Hall, Strict or Liberal Construction of Penal Statutes (1935) 48 HARv. L. REv. 748,771 .

62 Ibid.; Note [Allan Smith], Criminal Law-Statutory Corostruction (1938) 17 NEB. L. BULC. 203.

63 Kraus \& Bros. v. United States (1946) 327 U.S. 614. 
... or by way of ... trade understanding or otherwise". The district court held that the firm had violated the regulation, but the Supreme Court reversed the conviction. Justice Murphy, for the majority, argued that the quoted words were subject to "the same strict rule of construction that is applied to statutes defining criminal action" and, further:

... to say that the language ... applies to a case where the secondary product [i.e., the chicken feet] has value and is sold at its ceiling or market price, is to introduce an element of conjecture and to give effect to an unstated judgment of policy. ${ }^{54}$

The "unstated judgment of policy", of course, is that price control suffers when merchants are permitted to dump unwanted goods on customers who need scarce goods. ${ }^{55}$ It was just this judgment of policy that had influenced every lower court considering the question to reach a result contrary to the Supreme Court's. ${ }^{56}$ Moreover, the OPA had consistently ruled that compulsion to buy a secondary product was an illegal evasion of all its regulations; and this ruling had been stated in official interpretations issued prior to the date of the Kraus violation. ${ }^{5 T}$ As will be shown in subsequent pages, if Kraus \& Bros. had been defendant in treble damage or injunction proceedings, rather than in criminal proceedings, the chances are that the Court would have regarded these official interpretations as binding. ${ }^{58}$ Its opinion in this case suggests, therefore, the same queries that have arisen in statutory cases: (1) can words in a regulation mean one thing in civil proceedings and something else in criminal proceedings; and (2)

54 Ibid. at 621,624 . Justices Black, Reed, and Burton, dissenting, argued that the regulation "condemns all actions that are 'on the wrong side of the line indicated by the policy if not by the mere letter of the law.' Bullen v. Wisconsin (1916), 240 U.S. 625,631 ... What petitioner did liere is on the wrong side of both letter and policy." Ibid. at 631 .

55 The case is criticized in [April 6, 1946] Bread and Butter 3; cf. (1946) 14 Geo. WASH. L. REv. 647.

56 See United States v. Kraus \& Bros. (C. C. A. 2d, 1945) 149 F. (2d) 773; Bowles v. Coffin-Reddington Co. (N.D. Cahif. 1945), discussed in Coffin-Reddington Co. v. Porter (C. C. A. 9tli, 1946) 156 F. (2d) 113 ; Bowles v. Cudahy Packing Co. (W. D. Pa. 1945) 58 Fed. Supp. 748; Bowles v. Inland Trading Co. (N.D. Ind. 1944) 2 OPA, Op. \& Dec. 2243; Brown v. Banana Distributors (D. Conn. 1943) 52 Fed. Supp. 804; United States v. Armour \& Co. of Delaware (D. Mass. 1943) 50 Fed. Supp. 347; cf. Bowles v. S. S. Kresge Co. (W. D. Mo. 1945) 59 Fed. Supp. 427 ; and see United States v. N. B. Fairclougli \& Sons (D. N. J. 1946) 65 Fed. Supp. 453.

57 See Pike \& Fischer, OPA Service 2:812.

58 See Bowles v. Seminole Rock Co., infra note 73; Bowles v. Cudaby Packing Co. (C. C.A. 3d, 1946) 154 F. (2d) 891, 892. 
should regulations be interpreted strictly if the criminal cases arise first, but not so strictly if the first cases are civil? ${ }^{59}$

\section{The policy of the regulation}

Generally, the Court does not give the maxims of construction undue emphasis. Federal Reserve Bank v. Malloy held that a regulation dealing with bank collections did not supersede the common-law rule that banks must demand cash when presenting checks for payment. ${ }^{80}$ The glib justification would have been that regulations in derogation of the common law are strictly construed. Instead, the Court examined problems of bank collections with some care and concluded that this regulation was designed to cover only a special segment of those problems. In a case involving consular fees, regulations were read as an entirety, rather than seriatim by clauses. ${ }^{61}$ In a case holding that an ICC regulation required carriers to clear the ice from locomotive tenders, ${ }^{62}$ the Court rejected an argument sounding suspiciously like noscitur a sociis and, instead, adopted the approach of an earlier decision declaring that the "acts of Congress and orders of the Commission ... should be liberally construed, to ... promote the safety of trains and of persons and property thereon". ${ }^{63}$ This same idea was broadly restated in a pension case, where the Court commented: "The purpose in view is for consideration when the true meaning of statute or rule is sought." ${ }^{44}$ In a case where a draftee sought to compel the Secretary of War to give him an honorable discharge, the Court refused to adopt " $a$ judicial construction, contrary to the Army's construction, whereby respondent, who got no farther than his local board, would stand in a better status than the tens of thousands of other draftees who came much closer to complete integration into the Army than he ever did". ${ }^{65}$

59 Cf. S.E.C. v. Joiner Corp. (1943) 320 U. S. 344, 353, discussing Blue Sky laws: "The weight of authority is committed to a liberal construction, although some courts tend toward strict construction, and some have seemed to differentiate according to the use being made of the statute, inclining to a strict construction when a criminal penalty is being imposed and a more liberal one when civil remedies are being apphed."

60 (1924) 264 U.S. 160, 167.

61 United States v. Mosby (1890) 133 U.S. 273.

62 Lilly v. Grand Trunk R. Co. (1943) 317 U.S. 481, 487.

03 N.Y. Central R. R. Co. v. United States (1924) 265 U.S. $41,44$.

64 Hines v. Stein (1936) 298 U. S. 94, 98.

65 Patterson v. Lamb (1947) 329 U.S. 539, 544. And see Gibson v. United States (1946) 329 U.S. 338, 349 ("To construe the regulations otherwise would ... stretch the requirement of exhausting the administrative process beyond any reason supporting it."). 


\section{Administrative intent}

A fact to be noted in the cases already cited is that the Court has usually proceeded without reference to "administrative intent". This neglect can be contrasted with the Court's insistent emphasis upon "legislative intent" in most statutory disputes. ${ }^{66}$ In an ICC case, there was a passing reference to intent as showing meaning ("In using the word 'clean' the Commission must have meant something other than mere manner of construction or mechanical operation ....") ${ }^{07}$ and in the Ute Indians case the Court stressed intent in the sense of purpose ("The order was designed only to resolve the misunderstanding ..."). ${ }^{68}$ But in nearly all the other cases "meaning" was a search for what words meant, rather than what administrators meant; and to find "purpose" the Court discussed results it believed desirable, rather than results the administrators might have wanted. ${ }^{69}$

This seeming indifference to intent is puzzling when we look at other cases. Why, in litigation involving the FCC Rules of Practice, did Justice Frankfurter conclude that the FCC's interpretation of those rules was "binding upon the courts"? dozo declare that the Tariff Commission could "fix the meaning of ... its own rules and any phrase contained in them"? ${ }^{71}$ Clearly, they and their colleagues felt that the people who write a regulation and administer it should know best what it means. In other words, in these two instances they treated intent as the decisive fact, and they accepted administrative interpretations as the best evidence proving that fact.

Administrative interpretations vary greatly as to form. We have already noted, in discussing extrinsic aids, that the Court seems to accept them in all forms. ${ }^{72}$ Since agencies normally take part in law-

66 See Lyon, Old Statutes and New Constitution (1944) 44 Cor. L. Rev. 599, 627. But cf. Frankfurter, Some Reflections on the Reading of Statutes (1947) 47 ibid. 527, 538.

67 Lilly v. Grand Trunk R. Co. (1943) 317 U. S. 481, 487.

68 Supra note 23 , at 177 . The significance of the meaning-purpose dichotomy is explained in Jones, Statutory Doubts and Legislative Intention (1940) 40 CoL. L. REv. 957.

${ }^{69}$ Cf., however, Penn Dairies v. Milk Control Comm'n (1943) 318 U.S. 261, 277 ("That such is the meaning of the regulation is made plam by reference to the opinions of the Comptroller General, cited in the regulation."); Helvering v. Winmill (1938) 305 U.S. 79, 83 " "The special designation of security purchase commissions as a "part of the cost price of such securities' . . . cvinces the clear intent to withdraw that special type of commission from the general classification."); Ilinois Commerce Comm'n v. U.S. (1934) 292 U.S. 474, 487 (When ICC order is read with report, "there can be no doubt that it was intended" to cover intrastate traffic, as well as interstate.). It should be noted that in many cases counsel have not raised the question of adminisrative intent.

${ }^{70}$ Federal Comm'n v. Pottsville Broadcasting Co. (1940) 309 U. S. 134, 143, n. 6.

71 Norwegian Nitrogen Co. v. U. S. (1933) 288 U.S. 294, 325.

72 See notes 26-41, supra. 
suits involving their regulations, and can thus make known their interpretations whatever the form, we might assume that deferential pronouncements such as those by Justices Frankfurter and Cardozo would be common in Supreme Court opinions. In the recent Seminole case, involving OPA injunction proceedings, the Court did conclude that "the ultimate criterion is the administrative interpretation, which becomes of controlling weight unless it is plainly erroneous or inconsistent with the regulation". ${ }^{73}$ In a Wage-Hour case where a cannery claimed exemption on the ground that "all" its fruits came from nearby farms, when in fact $2 \%$ came from outlying areas, it was ruled that "the court below, in holding that ... all ... must be construed to mean 'substantially all', entered the Administrator's domain". ${ }^{\top 4}$ And in a Treasury case Justice Black suggested that "satisfactory proof of publicly established practice", under the applicable regulations, might have called for a decision favoring the government. ${ }^{75}$ These few cases, however, seem to stand alone as authority for a rule of deference; and they have not inhibited the Court in other cases from doing what it thinks just, regardless of what the interpretations proved may have implied as to administrative intent.

This basic independence is shown by holdings such as the Kraus chicken feet decision, where the Court has rejected agency rulings in favor of some maxim, or has echoed the dictum of fifty years ago that the interpretation of regulations "is for the court". ${ }^{76}$ There are kindred holdings which respect agency rulings only when the regulation's meaning is "doubtful", ${ }^{77}$ or which dilute the rule of deference with suggestions that rulings are "persuasive" but not binding. ${ }^{78}$ Even assuming the rule and accepting the Seminole language as its best statement, there is discretion to determine which rulings are "plainly erroneous or inconsistent with the regulation", and thus not worthy of

73 Bowles v. Seminole Rock Co. (1945) 325 U.S. $410,414$.

T4 Addison v. Holly Hill Co. (1944) 322 U.S. 607, 611.

Tu Levers v. Anderson (1945) 326 U.S. 219, 223.

76 Belden v. Chase (1893) 150 U. S. 674, 698. And see Brown Lumber Co. v. L. \& N. R. Co. (1937) 299 U.S. 393, 397; Note (1943) 93 L. J. 411, 412; cf. Davison, Admitristration and Judicial Self-Limitation (1936) 4 GEo. WASE. L. REv. 291, 306 ("Even with the official publication of the Federal Register we shall still have the period of great uncertainty as to the meaning of these thousands of executive orders until the more controversial ones can be interpreted by the federal courts.").

7T See Illinois Comm'n v. Thomson (1943) 318 U.S. 675, 684; cf. note 24, supra.

${ }^{78}$ See United States v. Eaton (1898) 169 U.S. 331, 342. The confusion caused by attempts to give agency interpretations less than binding effect is illustrated by cases dealing with statutes. See note 156 , infro. 
deference. The wide range of this discretion is exemplified by the conflict between majority and dissenters in the Ute Indians case. ${ }^{70}$

So we see that the cases lack consistency. The Court at times stresses words; at times, intent. Maxims of construction compete with considerations of policy. Agency rulings are both ignored and honored. The issues have been so scattered that we cannot even detect trends. There are no real guides to decision, and we must look further if we hope to isolate premises which may possibly lead us to reasonable rules for settling disputes.

\section{IOWER COURT CASES}

Questions as to the meaning of federal regulations have been major issues in countless lower court cases. The citations in this article alone represent disputes as to words enacted by the President, ${ }^{80}$ the Secretaries of State, ${ }^{81}$ War ${ }^{82}$ Agriculture, ${ }^{83}$ Interior, ${ }^{84}$ and the Treasury, ${ }^{85}$ the Postmaster General, ${ }^{86}$ the Director General of Railroads, ${ }^{87}$ the Interstate Commerce Commission, ${ }^{88}$ the Securities Exchange Commission, ${ }^{89}$ the Federal Communications Commission, ${ }^{00}$ the Tariff Commission, ${ }^{91}$ the Civil Service Commission, ${ }^{92}$ the Federal Reserve Board, ${ }^{93}$ the Social Security Board, ${ }^{94}$ the National Labor Relations Board, ${ }^{95}$ the Board of Supervising Steamboat Inspection, ${ }^{96}$ the Immigration and Naturalization Service, ${ }^{97}$ the Director of Selective Service, ${ }^{98}$ the Veterans Administration, ${ }^{99}$ the Civilian Production Admin-

${ }^{79}$ And see Bowles v. Dairymen's League Co-op Ass'n (S.D.N. Y. 1945) 61 Fed. Supp. 358.

80 Markham v. Taylor, infra note 148.

81 See United States v. Eaton, supra note 38.

82 See Garrison v. United States, supra note 21.

83 Fraser v. United States, infra note 137.

84 March Oil Co. v, Lee, infra note 151.

85 Day v. Laguna Land \& Water Co., infra note 155.

86 Johnston v. United States, infra note 130.

87 Rogers v. Union Pac. R. Co., infra note 107.

88 Raudenbush v. Baltimore \& O. R. Co., infra note 155.

89 S.E.C. v. Torr, infra note 107.

90 New England Tel. \& Tel. Co. v. U.S., infra note 186.

91 See Norwegian Nitrogen Co. v. U.S., supra note 41.

92 Borak v. Biddle, infra note 120 .

93 See Federal Reserve Bank v. Malloy, supra note 60.

04 Emlen v. Social Security Board, infra note 222.

05 National Labor Relations Board v. J. S. Popper, Inc., infra note 149.

96 The Norfolk, infra note 111.

${ }^{97}$ See Bridges v. Wixon, supra note 39.

${ }^{08}$ See Bartchy v. United States, supra note 22.

99 Collins v. United States, infra note 115. 
istration, ${ }^{100}$ the Solid Fuels Administration, ${ }^{101}$ the Federal Housing Administrator, ${ }^{102}$ the Federal Security Administrator, ${ }^{103}$ the WageHour Administrator, ${ }^{104}$ the Price Administrator, ${ }^{105}$ and others..$^{106}$

Strange to say, the cases are marked by an absence of cross-citation and a failure to heed Suprene Court decisions such as those already discussed. The attorneys and judges seem to have proceeded $m$ ignorance of the fact that precedents creating a law of interpretation were available. ${ }^{10 r}$ Thus, in the 102 non-OPA cases cited here as holdings turning on the meaning of a regulation, only 22 refer to interpretive precedents. ${ }^{108}$ Among 85 non-OPA cases where agency inter-

100 United States v. Alterman, infra note 114.

101 United States v. Peach Mountain Coal Min. Co., infra note 113.

102 Ferguson v. Union Nat. Bank of Clarksburg, W. Va., infra note 141.

103 Twin City Milk Producers Ass'n v. McNutt, infra note 174.

104 Walling v. Cohen, infra note 145.

105 Bowles v. Simon, infra note 113.

106 OPA cases probably outnumber those of all other agencies and are cited only to illustrate problems not raised elsewhere. For a complete listing, see "Interpretation" in the Topical Index to OPA, WEEKLY NEWS LETTER [Nov. 1943-June 1947], and also the OPA General Counsel's Index of Opimions of the U.S. Em. Ct. of Appeals [1942-1945].

${ }_{107}$ On occasion, attorneys overlook the interpretive questions. See Barry v. Reading Co. (C. C.A.3d, 1944) 147 F. (2d) 129, 133; cf. Gibson v. United States (1946) 329 U.S. 338, 341, n. 4 (" ... the important changes in the applicable regulations ... were not called to the attention of the trial courts or the Circuit Courts of Appeal."); State v. Olson (1944) 175 Ore. 98, 107, 151 P. (2d) 723, 727 ("The terms of the regulation do not appear in the pleading, but through the prolonged and patient efforts of a staff of hbrarians, Regulation No. 139 was discovered in the Federal Register . . . ."). On the other hand, there are surely many cases where well-briefed arguments were rejected by judges who refused to recognize an interpretive question as a real issue. $C f$. notes 14-22, supra, and for a lower court case see Rogers v. Union Pac. R. Co. (C. C. A. 9th, 1944) 145 F. (2d) 119, 123 ; cf. S.E.C. v. Torr (S. D. N.Y. 1936) 15 Fed. Supp. 144, 145; Caldwell Sugars v. United States (Ct. Cl. 1944) 54 Fed. Supp. 544, 551; United States v. Vogue, Inc. (C. C. A. 4th, 1944) 145 F. (2d) 609, 611. There are other cases where previous holdings regarding the interpretive question at issue were held controlling. See Bowles v. Good Luck Glove Co. (C. C. A. 7th, 1945) 150 F. (2d) 853 ; Dow Chemical Co. v. Kavanagh (C. C. A. 6th, 1943) 139 F. (2d) 42, 45; cf. El Paso \& S. W. R. Co. v. Phelps-Dodge Mercantile Co. (C. C.A. 9th, 1935) 75 F. (2d) 873; Eagle Cotton Oil Co. v. Southern Ry. Co. (C. C. A. 5th, 1931) 51 F. (2d) 443, 445.

108 These totals include 35 Supreme Court opimions, of which only 8 cite interpretive precedents. OPA cases are omitted from this and the following footnote because of the special instructions given to OPA attorneys concerning the rule of deference. See Norem, The "Official Interpretation" of Administrative Regulations (1947) 32 IowA L. REV. 697, 707; cf. note 106, supra. Garrison v. United States, supra note 21, was cited in Ferguson v. Union Nat. Bank of Clarksburg (C. C. A. 4th, 1942) 126 F. (2d) 753, 758, as authority for the maxim that regulations are to be strictly construed against the Government. But the language in the Garrison case referring to that maxim pertained not to a regulation but to a Government contract. 
pretations were proved, only 22 refer to the rule of deference. ${ }^{100}$ In 20 cases, the judges seemed willing to decide what a regulation meant without any authentic information as to what the coguizant agency thought it meant. ${ }^{110}$

The impact that precedent might have had on some of these cases is easily shown. The court of appeals for the second circuit, affirming the conviction of one Helmut Leiner for trading with a Nazi agent, admitted that its interpretation of the applicable regulation "does violence to its terms". 111 The opinion is carefully written, but the citation of the $A d d y$ case, declaring that such regulations are to be construed "as criminal statutes are-strictly", might have called for even more explanation. ${ }^{112}$ The district judge in Indiana who, during the war, permitted a landlord to lease a garage to one of his tenants at an unapproved rental, should perhaps have been reminded that "The purpose in view is for consideration when the true meaning of statute or rule is sought". ${ }^{113}$ As to the rule of deference, one wonders why government attorneys allowed a district judge in Louisiana to interpret a WPB regulation, very technical in its requirements, without evidence as to what the WPB had in mind. ${ }^{114}$ Or why, when argu-

100 These totals include 31 Supreme Court opinions, of which only 8 refer to the rule. The interpretations sponsored by agencies were rejected in over half of the 62 cases which ignore the rule, but in only 2 of the 22 cases which refer to the rule.

110 This total includes 3 Supreme Court cases. And see note 155, infra.

111 United States v. Leiner (C. C. A. 2d, 1944) 143 F. (2d) 298, 300. Cf. The Norfolk (D. Md. 1921) 297 Fed. 251, 255 ("Pilot Rule 2 . . cannot be taken literally.").

112 Supra note 47. And cf. Bowles v. Eastern Sugar Associates (D. Md. 1946) 64 Fed. Supp. 509, 513 (" . . . if the Office of Price Administration, in drafting its regulations, is unable to say what it means in reasonably clear language, the public should not be penalized, but should be given the advantage of the ambiguity.").

113 See Bowles v. Simon (C. C. A. 7th, 1944) 145 F. (2d) 334, 337; and cf. Hines v. Stein, supra note 64 . For a case where the court was influenced by purpose, see Bowles v. Co-operative G. L. F. Farm Products (W.D.N.Y. 1943) 53 Fed. Supp. 413, 415 ("Such construction would practically eliminate any market for eggs for sale by the retailer to ... the housewife.") ; of. United States v. Peach Mountain Coal Min. Co. (C.C.A. 2d, 1947) $161 \mathrm{~F}$. (2d) 476, 480 (judges disagree as to purpose).

114 Bowles v. Rivet-Causey Ready-to-Wear (W. D. La. 1944) 53 Fed. Supp. 730, As to the relevance of WPB intent, see Hawkins and Wallace, Antitrust During National Emergencies-Executive Immunity (1945) 24 TEx. L. REv. 51, 67. In Crowley v. Commodity Exchange (C. C. A. 2d, 1944) 141 F. (2d) 182, 189, the attorneys for the Alien Property Custodian seem to have argued about two OPM regulations without introducing evidence as to OPM intention. $C f$. the comment on Porter v. Consolidated Badger Cooperative (C. C. A. 7th, 1946) 157 F. (2d) 835, in 3 OPA, WeEkLY NEws LETTER (Nov. 25, 1946) 1050 (" ... in the future, in the trial of any case involving regulations or orders of another agency or department, attorneys should obtain and introduce into evidence interpretations of such orders or regulations made by such agency or department. This should tend to avoid the instant result."). And see United States v. Alterman 
ing a G.I. Insurance claim, they allowed an appellate court to speculate as to the intent of the Veterans Administration, without evidence as to that agency's real intent. ${ }^{115}$ Or why the attorneys for the employer, in a Wage-Hour case, let the court comment that "we do not think that the administrator could have meant exactly what he said", without evidence as to what he did inean. ${ }^{116}$ Similarly, in litigation where the Wage-Hour Administration is plaintiff, a holding that its representatives erred in analyzing the "purpose in the drafting of the order" ought to call for some mention of the fact that administrators usually analyze their purposes correctly. ${ }^{117}$ Also, where the Commissioner of Internal Revenue is defendant, a statement of the "theory" of a regulation contrary to the statement of his representatives would seem to call for acknowledgment of the fact that administrators normally state their theories correctly. ${ }^{11 s}$

\section{The diffusion of doctrine}

An even more significant product of the failure to use interpretive precedents is a hodgepodge of theories, rules, and cautions, all pertaining to regulations, that can now be exploited by opposing lawyers in almost every dispute. We find, first, a steady recurrence of the problem met in the Ute Indians case: When are words so plain that they can reasonably support but one meaning? ${ }^{119}$ Judges do not like interpretations that are "tortured", ${ }^{120}$ or "strained and unnatural"; $;$ "121 and the purpose in view cannot override the express language, "if clear and

(S.D.Fla. 1947) 4 ibid. (March 3, 1947) 202 (court construes Priorities Regulation 33 without reference to contra statements in Interpretation 1, issued Oct. 31, 1946); cf. Porter v. Little (C. C. A. 9th, 1946) 158 F. (2d) 707, 709 (interpretation by issuing agency used effectively).

115 Collins v. United States (C. C. A. 10th, 1947) 161 F. (2d) 64, 69.

116 George Lawley \& Son Corporation v. South (C. C. A. Ist, 1944) 140 F. (2d) 439, 444; cf. Addison v. Holly Hill Co., supra note 74.

117 Cf. Walling v. Baltimore Steam Packet Co. (C. C. A. 4th, 1944) 144 F. (2d) 130, 136; and see Bowles v. Livingston (C. C. A. 5th, 1946) 157 F. (2d) 800, 802 ("Fixing new prices ... would have been a terrible burden on O.P.A., and we believe was never attempted or required."); Southern Goods Corporation v. Bowles (C. C. A. 4th, 1946) $158 \mathrm{~F}$. (2d) 587,590 ("No such ridiculous situation could have been contemplated.").

118 Cf. Nichols v. Commissioner of Internal Revenue (C. C. A. 6th, 1944) 141 F. (2d) 870, 876; Levitt \& Sons v. Nunan (C. C. A. 2d, 1944) 142 F. (2d) 795, 797; New Idria Quicksilver Min. Co. v. Commissioner of Internal Rev. (C. C. A. 9th, 1944) 144 F. (2d) 918,921 ("We believe the interpretation of the regulation by the Commissioner and the Tax Court is not in harmony with . . the intention of the regulation.").

110 E.g., see S. S. White Dental Mfg. Co. v. United States (Ct. Cl. 1944) 55 Fed. Supp. 117 ; and $c f$. note 24 , supra.

120 Borak v. Biddle (App. D. C., 1944) 141 F. (2d) 278, 281.

121 Barron Coop Creamery v. Wickard (C. C. A. 7th, 1944) 140 F. (2d) 485, 488. 
unambiguous". ${ }^{122}$ Nevertheless, "it is reasonable and practicable certainty, and not legalistic preciseness, that is the sound criterion"; words must not be lifted out of their "natural setting"; ${ }^{124}$ and the policy of a regulation may "ameliorate its seeming harshness" and "qualify its apparent absolutes". ${ }^{125}$

Concerning detail, the plural can include the singular; ${ }^{120}$ "the body of the enactment controls the title"; ${ }^{127}$ and, though regulations dealing with the same subject are to be construed in pari materia, ${ }^{128}$ parallel phrases in different regulations need not be given the same interpretation. ${ }^{129}$ The word "trustee", if not defined, must be understood in its "natural and most obvious import"; ${ }^{130}$ and words like "broker", "in use", and "charges" will be construed in line with precedents regarding other contexts. ${ }^{131}$ But "judicial sale" may comprehend more than it strictly describes; ${ }^{132}$ "lease, for a term" may transcend the vagaries of property law; ${ }^{133}$ price regulations are not bounded by the Sales Act; ${ }^{134}$ and, for tax purposes, the language of accountants and economists will not set the meaning of "income". ${ }^{135}$ Absence of definition is not necessarily significant, ${ }^{136}$ but "purpose

122 Bowles v. 870 Seventh Avenue Corporation (C. C. A. 2d, 1945) 150 F. (2d) 819, 821.

123 Pearson v. Walling (C. C. A. 8th, 1943) 138 F. (2d) 655, 659.

124 John L. Denning \& Co. v. Fleming (C. C. A. 10th, 1947) 160 F. (2d) 697, 701.

125 Porter v. Nowak (C. C. A. 1st, 1946) 157 F. (2d) 824, 825.

128 Bowles v. Texas Liquor Control Board (C. C. A. 5th, 1944) 146 F. (2d) 155, 157.

127 Lomhard Trustees v. Com'r of Internal Revenue (C. C. A. 9th, 1943) 136 F.

(2d) $22,23$.

128 Alan Levin Foundation v. Bowles (Em. Ct. 1945) 152 F. (2d) 467, 470.

129 Buckeye Parking Corporation v. Bowles (Em. Ct. 1944) 141 F. (2d) 692, 694.

130 Birmingham v. Central Life Assur. Soc. (C. C. A. 8th, 1944) 141 F. (2d) 116, 120; cf. Johnston v. United States (C. C. A. 9th, 1944) 145 F. (2d) 137, 138 (dictionary definition controls "purchase").

131. Bowles v. Sisk (C. C. A. 4th, 1944) 144 F. (2d) 163, 164; Raudenbush v. Baltimore \& O. R. Co. (C. C.A. 3d, 1947) 160 F. (2d) 363, 367; Pufahl v. Bowles (C. C. A. 8th, 1946) 154 F.' (2d) 427,430 . And see Brown v. Southwestern Furs, Inc. (S. D. N.Y. (1943) 1 CCH, Price Control Cases $\llbracket 51,941$ ("brokerage"); Texas Co. v. Higgins (C. C. A. 2d, 1941) 118 F. (2d) 636, 638 ("employee").

132 Bowles v. Texas Liquor Control Board (C. C. A. 5th, 1944) 146 F. (2d) 155. 133 Patrick Cudaby Family Co. v. Bowles (Em. Ct. 1943) 138 F. (2d) 574, 575. 134 United States v. Lutz (C. C.A. 3d, 1944) 142 F. (2d) 985, 989; Swanee Fahries, Inc. v. American Bleached Goods Co. (N.Y. City Ct. 1942) 103 N.Y. L. J. 148. But of. Bowles v. Schille (E.D. Wis. 1945) 2 OPA, Op. \& Dec. 2336; and see Porter v. Kaplan (D. Minn. 1946) 4 ibid. 2271 (miscellaneous precedents cited for rules distinguishing a sale from a contract).

135 Helvering v. Edison Bros. Stores (C. C. A. 8th, 1943) 133 F. (2d) 575, 579.

136 Bowles v. Co-operative G. L. F. Farm Froducts (W.D.N. Y. 1943) 53 Fed. Supp. 413, 415. But cf. General Motors Acceptance Corporation v. Higgins (C. C.A. 2d, 
and not inadvertence" will be presumed when a rule is specified for one situation and not another..$^{137}$ An intent to distinguish is presumed when words such as "unless" and "until", or "executive" and "administrative", or "maintain" and "repair" are used conjunctively. ${ }^{138}$ Expressio unius has been both adopted and rejected; ${ }^{139}$ ejusdem generis, rejected (but only on a technicality).$^{140}$

Regulations are to be construed strictly agamst the government. ${ }^{141}$ When in doubt, courts will "incline against interference by the federal governinent with the proper governmental activities of a State"; ${ }^{142}$ and if there is power to impose "a drastic liability, certainly its exercise should be in the clearest words". ${ }^{143}$ All regulations, however, are presumed valid; ${ }^{144}$ and those accompanying a remedial statute merit the "same liberality of construction" as the statute itself. ${ }^{145}$ Retroactivity $^{146}$ and repeals by implication ${ }^{14 i}$ are not favored.

The patchwork is most fantastic in the rule-of-deference cases.

1947) $161 \mathrm{~F}$. (2d) 593, 596 ("Treasury Regulations 71 promulgated in connection with the statute do not expressly define the word 'debenture' and by implication its meaning was considered by the treasury to be too well understood to require such definition.").

13T Fraser v. United States (C. C. A. 6th, 1944) 145 F. (2d) 139, 142.

138 Goodman v. Bowles (Em. Ct. 1943) 138 F. (2d) 917, 919; Automatic Fire Alarm Co. v. Bowles (Em. Ct. 1944) 143 F. (2d) 602, 606; Stanger v. Glenn I. Martin Co. (D.Md. 1944) 56 Fed. Supp. 163, 166. And see George Lawley \& Son Corporation v. South (C. C. A. 1st, 1944) $140 \mathrm{~F}$. (2d) 439 (words written in disjunctive distinguished from words written in conjunctive).

139 Compare Pinkerton's Nat. D. Agency v. Fidelity \& D. Co. of Md. (C. C. A. 7th, 1943) 138 F. (2d) 469, 471, with Bowles v. American Brewery (C. C. A. 4th, 1945) 146 F. (2d) 842, 845. And see Brown v. Bayview Manor Homes (E. D. Va. 1943) 51 Fed. Supp. 557, 558 ("If the Administrator had determined to prohibit the requiring of security ...., the regulations would have so provided."); Herrman v. Lyle (W. D. Wash. 1930) $41 \mathrm{~F}$. (2d) 759,761 ("Expressum facit cessare tacitum ... determinative").

140 Pearson v. Walling (C. C. A. 8th, 1943) 138 F. (2d) $655,659$.

141 Ferguson v. Union Nat. Bank of Clarksburg, W. Va. (C. C. A. 4th, 1942) 126 F. (2d) 753,758 .

142 Bowles v. Texas Liquor Control Board (C. C. A. 5th, 1944) 146 F. (2d) 155, 157. 143 New England Dairies v. Wickard (C. C. A. 2d, 1944) 144 F. (2d) 460, 462.

144 Pinkerton's Nat. D. Agency v. Fidelity \& D. Co. of Md. (C. C. A. 7th, 1943) 138 F. (2d) 469, 472; Lowden v. Iroquois Coal Co. (N. D. Ill. 1937) 18 Fed. Supp. 923, 925. The presumption favoring validity had peculiar effect in OPA cases, since the validity of an OPA regulation could be questioned only in the Emergency Court of Appeals, Yakns v. United States (1944) 321 U.S. 414, 427. Nevertheless, the district and circuit courts frequently rejected interpretations sponsored by OPA on the ground that, thus interpreted, the regulation imght be invalid. E.g., Sullivan v. Porter (C. C. A. 5th, 1947) $160 \mathrm{~F}$. (2d) $648,649$.

145 Ralph Knight v. Mantel (C. C. A. 8th, 1943) 135 F. (2d) 514, 517; Walling v. Cohen (C. C. A. 3d, 1944) 140 F. (2d) $453,456$.

148 Bowles v. Lake Lucerne Plaza (C. C. A. 5th, 1945) 148 F. (2d) $967,970$.

147 See Englander v. Porter (S.D.N.Y. 1946) 5 OPA, Op. \& Dec. 7012. 
As we have seen, some judges reject agency interpretations without even a nod at the rule. Their opinions contrast with others which state that the agency ruling is "binding", 148 unless "so arbitrary as to result in the denial of substantial justice", 140 or "capricious and arbitrary", ${ }^{150}$ or "clearly erroneous". ${ }^{151}$ In between are opinions which give the rulings "great weight", 152 or adopt them when they seem correct, ${ }^{153}$ or merely treat them as precedents. ${ }^{154}$

\section{HOW SHOULD COURTS INTERPRET REGULATIONS?}

The rule-of-deference cases are of special interest for two reasons. First, they are precedents for nearly all other cases (since, as noted above, agencies do take part in most lawsuits that concern regulations).${ }^{155}$ Second, they highlight the fact that the task of interpreting

148 Glen Alden Coal Co. v. National Labor Relations Board (C. C. A. 3d, 1944) 141

F. (2d) 47, 52; cf. Markham v. Taylor (S.D.N.Y. 1947) 70 Fed. Supp. 202, 205.

149 National Labor Relations Board v. J. S. Popper, Inc. (C. C. A. 3d, 1940) 113 F. (2d) 602,603 .

150 Walling v. Cohen (C. C. A. 3d, 1944) 140 F. (2d) 453, 456; Walling v. Brooklyn Braid Co. (C. C.A. 2d, 1945) 152 F. (2d) $938,940$.

151. March Oil Co. v. Lee (1924) 113 Okla. 242, 246, 241 Pac. 804, 807. Accord: Armstrong Co. v. Walling (C. C.A. 1st, 1947) 161 F. (2d) 515, 517; Green Valley Creamery v. United States (C.C.A. 1st, 1939) 108 F. (2d) 342, 347; and see Hitchcock v. United States ex rel. Bigboy (1903) 22 App. D. C. 275, 287.

152 Fort Worth \& Denver City Ry. Co. v. Childress Cotton Oil Co. (N.D. Tex. 1942) 48 Fed. Supp. 937, 940; Froeber-Norfleet v. Southern Ry. Co. (N.D. Ga. 1934) 9 Fed. Supp. 409, 411; cf. Southern Goods Corporation v. Bowles (C.C. A. 4th, 1946) 158 F. (2d) 587,590 (rule of Seminole case whittled down to "respectful consideration"). 153 Queensboro Farms Products v. Wickard (C. C. A. 2d, 1943) 137 F. (2d) 969, 981; cf. LeRoy Dyal Co. v. Allen (C. C. A. 4th, 1947) 161 F. (2d) 152, 159 ("We see no occasion to depart from this construction of the regulation by the issuing authority."). 154 Dumas v. King (C. C. A. 8th, 1946) 157 F. (2d) 463, 466; Commissioner of Int. Rev, v. Air Reduction Co. (C. C. A. 2d, 1942) 130 F. (2d) 145, 148; cf. Fleming v. Campbell (C. C. A. 6th, 1947) $160 \mathrm{~F}$. (2d) 315, 318. But see Mechanical Farm Equipment Distributors v. Porter (C. C.A. 9th, 1946) 156 F. (2d) 296, 298 ("Appellant . . . cites cases which narrowly construed the word 'commercial' or like words . . . in variously unrelated statutes .... In view of the Administrator's interpretation, however, we do not find these cases persuasive.").

155 For a discussion of cases where agencies lave not participated, see Beuscher, Public Representation in Private Litigation Involving Administrative Rules [1942] Wis. L. REv. 355. And compare Illinois Comm'n v. Thomson (1943) 318 U. S. 675, 681 (ICC requested to file brief discussing "meaning and application" of its rate order), with Raudenbush v. Baltimore \& O. R. Co. (C.C.A.3d, 1947) 160 F. (2d) 363 (ICC not requested to discuss its safety rule). Also see Sinift v. Sinift (1940) 299 Iowa 56, 88, 293 N. W. 841, 856; Day v. Laguna Land \& Water Co. (1931) 115 Cal. App. 221, 1 P. (2d) 448 (Treasury not requested to discuss its regulations). Cf. Bowles v. Seminole Rock Co. (1945) 325 U.S. 410, 413 ("Since this involves an interpretation of an administrative regulation a court must necessarily look to the administrative construction of the regulation if the meaning of the words used is in doubt."); Bowman v. Bowles (Em. 
regulations differs from the task of interpreting statutes. In recent years, judges have written innumerable opinions dealing with agency interpretations of statutes. ${ }^{156}$ The problems considered in these opinions, though parallel, are not the same as the problems in regulations cases. In both, judges decide whether they should defer to the agency determination. But in reviewing an agency interpretation of a statute, they study the authority delegated by Congress and determine whether it has been exceeded. ${ }^{15 \pi}$ In reviewing the interpretation of a regulation, the crucial question is not authority. The typical case involves no contention that, as construed by the administrator, the regulation is invalid or that his interpretation, if stated as an amendment, would have exceeded his authority. ${ }^{158}$ The claim is rather that, by interpreting, he has not achieved results he could have ensured by amending. The crucial question is fornality; and attorneys attacking the administrator's ruling argue that his "I mean" (the informal ruling) has less effect than his "I amend" (the formal ruling).

Thus, in a recent ninth circuit case, the court observed: "The Price Administrator is empowered to alter a status created by a prior regulation only by an order or another regulation ... . Price Interpretation No. 29 . . is neither." "159 And in the Kraus chicken feet case, if the ruling that "any arrangement by which a seller conditions the sale of a commodity ... upon the purchase by the buyer of any other commodity ... constitutes a violation" 160 had (1) been approved by Leon Henderson (and not merely an assistant general counsel), and (2) been published in the Federal Register (and not merely in a document entitled Recent Price Interpretations), Justice Murphy could

Ct. 1944) 140 F. (2d) 974,977 (litigants must first raise interpretive issues in administrative proceedings).

156 See Notes (1942) 56 HaRv. L. Rev. 100; (1939) 84 L. Ed. 28; cf. Eisenstem, Some Iconoclastic Reflections on Tax Administration (1945) 58 HARv. L. REv. 477 ; Note (1945) 59 HARv. L. REv. 119, 125.

157 Compare Gray v. Powell (1941) 314 U.S. 402, with Addison v. Holly Hill Co. (1944) 322 U.S. 607; and see Morgenthau, Implied Regulatory Powers in Administrative Law (1943) 28 IOWA L. REv. 575.

158 Cf. Conklin Pen Co. v. Bowles (Em. Ct. 1946) 152 F. (2d) 764, 766 (contention made that regulation was invalid); and see note 144 , supra.

159 F. Uri \& Co. v. Bowles (C. C. A. 9th, 1945) 152 F. (2d) 713, 718. Cf. the following statement, which appears in a letter of June 4,1942, addressed by the General Counsel of OPA to the Counsel for the National Retail Dry Goods Association: "In your letter you criticize what you term 'the general practice of amending the text of orders by interpretation'. The Office of Price Administration engages in no such practice. Any regulation or order issued by the Administrator is amended or modified only by the Administrator acting pursuant to lis authority under the Emergency Price Control Act." 160 Supre note 57. 
not have concluded that "an unstated judgment of policy" prejudiced the defendants. The judgment of policy would have been stated, as an amendment; and the Justice himself conceded that, so stated, the ruling would have been immune from Court attack. ${ }^{101}$

In cases involving statutory interpretation, the agency has no power to amend. In cases involving interpretation of regulations, the agency does have power to amend ${ }^{102}$ but has chosen imstead to interpret. Should this choice be sigmificant? Nearly fifty years ago, the court of appeals for the District of Columbia commented:

It was within the power of that executive department [Dept. of Interior], or of the President, as its final chief and head ... to make the regulation express in specific terms that which the department now claims that it was intended to mean. And if the President could do that, as beyond question he could, why should courts repudiate the construction which the Secretary and the Commissioner, acting under his authority, place upon the regulation. ${ }^{163}$

Admimistrators do not quite have Iolanthe's power to change laws by penciled alterations, but they have almost that power. ${ }^{104}$ Amend-

101 Supra note 42, at 622 ; cf. Bowles v. Jones (C. C. A. 10th, 1945) 151 F. (2d) 232 (proceedings based upon violation of amended regulation sustained even though administrator acknowledged that mistake had been made in issuing amendment); Baggett v. Fleming (C.C.A. 10th, 1947) 160 F. (2d) 651,654 ("If the regulation seems harsh and unreasonable, rehief lies elsewhere."). But see Porter v. Cole (N.D.Tex. 1946) 66 Fed. Supp. 11, 12; cf. note 144, supra.

162 In a few instances Congress has formally adopted a regulation. E.g., 59 STAT. (1945) 624, 38 U.S. C. (Supp. 1946) pt. VIII of note following c. 12 (complex Congressional amendments of Veterans Regulation Numbered 1 (a), as amended) ; cf. 54 STAT. (1940) 179,12 U.S. C. $\$ 95$ a (foreign funds control approved). In cases relating to such regulations, it might be held that the administrator has no power to amend; if so, rules of statutory interpretation should apply.

163 Hitchcock v. United States ex rel. Bigboy (1903) 22 App. D. C. 275, 287; and see (1895) 21 Op. Atty. Gen. 255, 259 ("You ask me a further question which seems to involve the construction or application of one of the Customs Regulations of 1892. These are regulations formulated by your predecessor, and which you bave the power to modify at any time. For these reasons their construction is not a proper subject of an opinion by the Attorney-General."). Cf. "President to Biddle" in The Washington Post, Nov. 7, 1943, at 1 ("The President overruled Comptroller General Lindsay Warren's recent opinion that the obligation imposed by an executive order on contracting agencies to incorporate a nondiscrimination elause in each contract awarded by them was not a mandatory requirement, but inerely a directive." ").

104 The following is from Act II of the Gilbert and Sullivan opera: "QuEEN: ... (unfolding a scroll) the law is clear-every fairy must die who marries a mortall

LORD CE: . . . The subtleties of the legal mind are equal to the emergency . . . the insertion of a single word will do it. Let it stand that every fairy shall die who doesn't marry a mortal.....

QUEEN: ... Very well (altering the MIS. in pencil)." 
ments are often planned, drafted, signed and filed within a few days -at times within a few hours. For some judges, this fact strengthens an agency interpretation since, had doubt as to its correctness been foreseen, the administrators could easily have issued it as an amendment. ${ }^{105}$ Other judges conclude that ease of amendment dispels any real need for deference, on the ground that administrators can redress judicial error without difficulty. The court of appeals for the fifth circuit, for example, recently made this comment:

... if we have misconstrued the Order, or if experience shall show a nore drastic regulation to be necessary, he [the administrator] can nuake a new one. ${ }^{16 B}$

Unfortunately, judicial error cannot always be redressed without difficulty. The Seminole case, mentioned above, is an illustration. Both the district court and the circuit court held that the OPA's interpretation of its General Maximum Price Regulation was incorrect. The regnlation had been in effect for nearly two years when the judgment was entered. The interpretation, issued concurrently with the regulation, appeared in a bulletin entitled What Every Retailer Should Know About the General Maximum Price Regulation. Leon Henderson had signed the bulletin, and its purpose was to explain lawyer's language to laymen. It was not published in the Federal Register, but hundreds of thousands of copies had been distributed throughout the country.

The Supreme Court decided that the lower courts had erred, and announced that "the administrative interpretation ... . becomes of controlling weight unless it is plainly erroneous or inconsistent with the regulation". ${ }^{107}$ If the error had not been corrected on appeal, the OPA could not possibly have redressed the harm done. The interpretation

105 Cf. Dick v. Morris Heights Realty Corp. (S. D.N.Y. 1943) 5 PIRE AND FIsCHER, AD. LAw, Dec. Note No. 678 ("The interpretation of a regulation by the administrative body which issued it must be given consideration, whether the interpretation be regarded simply as an interpretation of the meaning of its regulation, or a modification thereof effective in the, future. This is especially so in this case in which the Regulation became effective after the interpretation was issued." [Italics supplied.]).

100 Bowles v. Texas Liquor Control Board (C. C. A. 5th, 1944) 146 F. (2d) 155, 157; and see In re Middletown Milk \& Cream Co., Inc. (Dept. Ag. 1944) Pike ANd Fiscrere, AD. LAw 33j. 213-8, 14; cf. the discussion of Fleming v. Myers (C. C. A. 9th, 1947) 159 F. (2d) 210 in 4 OPA, WEEkLY NEws LETIER (Feb. 17, 1944) 144 ("The language involved has long since been changed so that it is doubtful whether the decision will affect us adversely in many future cases.").

$16 \pi$ Supra note 73. 
reflected an anti-inflationary policy assumed to be obvious. ${ }^{10 s}$ An amendment restating the interpretation might have enforced that policy for the future but would have been unfair to the conscientious sellers who, for two years, had been prejudiced competitively because they had observed the policy.

\section{When interpretations are like amendments}

We might suppose that administrators use amendments when they change law and interpretations when they clarify law. Actually, the processes are not distinct. Administrators do amend when they think the plain meaning of a regulation is opposed to what they want. ${ }^{169}$ But we have seen that people disagree as to the confines of "plain meaning". When, therefore, literal-minded admimistrators overrule their more venturesome colleagues, amendments result that might have been upheld as interpretations. ${ }^{1 \pi 0}$ Moreover, some amendments are not intended to change the meaning of a regulation. They are mere clarifications but are issued in amendatory form so that the agency can publicize them better, or more conveniently collate them, ${ }^{171}$ or (considering present uncertainty as to the rule of deference) more confidently tell courts that it really means business. ${ }^{172}$

108 The issue was whether "highest price ... charged ... for delivery ... during March, 1942" meant highest price charged for (1) an item delivered in March, regardless of when it had been offered for sale, or (2) an item that had been hoth offered for salo and delivered during March. Offering prices in the Spring of 1942 were at inflationary levels; and the OPA wanted its ceilings set by March delivery prices, which generally reflected offers made during the Winter. If its interpretation had been overruled, a seller would have been required to use his March delivery prices only when they also reflected his March offering prices.

169 E.g., OPA Teletype Broadcast 31 WA 9-30-42 ("Atlanta queries reasoning behind our teletype 31 WA 9-2-42 that 'GMPR not MPR 133, covers sales of used parts talken from trade-in farm machinery at all levels'. We recognize that the interpretation is difficult to justify on the basis of the wording of the regulation. The interpretation was based upon the intent of those who drafted the regulation and upon the practical impossibility of determining maximum prices for used parts in accordance with MPR 133. For your infornation, this interpretation is only an interim measure pending an amendment to MPR 133 which either will specifically exclude such parts or will provide a suitable means of determining maximum prices for them.").

$170 \mathrm{Cf}$. Bowles v. Bayview Manor Homes (C. C. A. 4th, 1944) I45 F. (2d) 618, 619 ("In view of the amendment ... the question as to whether the original regulation should be construed as forbidding security deposits has . . become a mere moot question."); and see Mechanical Farm Equipment Distributors v. Porter (C. C. A. 9th, 1946) 156 F. (2d) 296,298, n. 2 .

171 E.g., Appendix A of Amendment 2 to MPR 220, supra note 7; cf. Senderowitz v. Clark (Em. Ct. June 30, 1947) 162 F. (2d) 912, 917, n. 1.

172 See Miller v. Loesch (Cir. Ct., Comm'r's Ct., Wayne Co., Mich., 1944) quoted in OPA, WEEKLY NEwS LETTER (Dec. 4, 1944) 22, 23 (" . . the various courts found 
Why do administrators say "The meaning is" rather than "The law is"? In many instances they may not have authority to pronounce law. Thus we can easily distinguish, from amendments, interpretations by one agency of another's regulations; we can also distinguish the miscellaneous advisory opinions and other interpretive rulings of field offices. ${ }^{172 a}$ Even in central offices we can cull out the edicts of receptionists, consultants, and run-of-the-mill lawyers, as well as offhand statements (made, say, in telephone conversations or at public meetings) that can hardly be treated as amendatory though made by the chief himself.

Deliberative rulings approved by top officials are sometimes phrased as interpretations in order to avoid amendment procedures. These procedures are usually planned to ensure public participation in rule-making, or to guarantee administrative review. ${ }^{173}$ Since an interpretation issued without regard to their requirements has not been exposed to the kind of participation or review deemed advisable for amendments, it should not be given amendatory effect. ${ }^{174}$ In cases

his position untenable; and in substance advised him that courts could not understand why he relied upon the vagaries of implicity when he had the absolute right to be explicit in his Regulations. Apparently, even Price Administrators are human and susceptible to hints, for on September 1, 1944 the Rent Regulations were amended . . . "); 4 ibid. (Mar. 17, 1947) 232 (After Fleming v. Campbell (C. C. A. 6th, 1947) 160 F. (2d) 315 held OPA interpretation was incorrect, Litigation Division suggests "possibility of an amendment" to Rent Division.).

172a See Cintron v. Bull Insular Line (C. C. A. 1st, Nov. 7, 1947) 164 F. (2d) 88. 173 See Atty. Gen.'s Comm. on Admin. Proced., Final Report, SEN. Doc. No. 8, 77th Cong. 1st Sess. (1941) 101; cf. Pritchett, The Supreme Court and Administrative Regulation, 1941-1944 (1945) 31 Iowa L. REv. 103, 111. A few agencies have set up special procedures for interpretive rulings (e.g., see Gaguine, The Federal Alcoliol Administration (1939) 7 GEO. WASH. L. REv. 949, 954); but the typical assumption of both legislators and administrators is that interpretations do not need exposure to hearings, formal or informal. Cf. H. R. REP. No. 1980, 79th Cong. 2d Sess. (1946) 24 (discussing exemption of "interpretative rules" from rule-making requirements of Admimistrative Procedure Act); SEN. Doc. No. 10, 77th Cong. 1st. Sess. (1941) pt. 1, 67 (investigators for Atty. Gen.'s Comm. on Admin. Proced. query whether "the problein of general definition was one wholly of legal interpretation, upon which affected persons could shed httle hight"); and see Jewell Ridge Coal Corporation v. Local No. 6167, etc. (D. Va. 1944) 53 Fed. Supp. $935,945, r e v^{\prime} d,(1945) 325$ U.S. 161.

174 Cf. Barron Coop. Creamery v. Wickard (C. C. A. 7th, 1944) 140 F. (2d) 485 , 488 (" . . the construction which the Secretary seeks was not considered at the public hearings held for the formulation and promulgation of Order 41."). But compare Fishgold v. Sullivan Corp. (1946) 328 U. S. 275, 290 (" . . his rulings are not made in adversary proceedings and are not entitled to the weight which is accorded interpretations by administrative agencies entrusted with the responsibility of making inter partes decisions."), with Skidmore v. Swift \& Co. (1944) 323 U. S. 134, 140 ("The fact that the Administrator's policies and standards are not reached by trial in adversary form does 
where the procedure for amendments has been followed, however (as in cases where no procedure is prescribed), the details of issuance do not distinguish an amendment from a properly authenticated interpretation.

On occasion, notwithstanding the approval of top officials, agencies tell us that their interpretations are not to be viewed as authoritative. The V.A. pamphlet on readjustment allowances, for example, states, "Material contained in this publication ... does not, nor is it intended to, have the force or effect of laws, rules, or regulations." 175 But most duly approved interpretations are not thus qualified. What Every Retailer Should Know about the General Maximum Price Regulation, for example, contains no hint of ambivalence as to retailers' responsibilities. The OPA did say "The meaning is", rather than "The law is"; but the real message was, "Here is what we want you to do, and you'd better do it."

Thus, administrators who want an interpretation to be law often fail to pronounce that it is law. Why? In some instances, they fear that an amendment would be looked upon as a change when, in fact, they intend only to clarify. In a recent case involving an amendment to Milk Order 41, the Secretary of Agriculture argued that he had intended only to clarify and that the order itself should be held applicable to facts occurring prior to the date of the amendment. The court, however, ruled that the amendment was "tantamount to an admission by the Secretary that the order as originally promulgated did not [apply]". ${ }^{176}$ This inference would have been unjustified if the Secretary had used interpretive rather than amendatory words. ${ }^{1 i 7}$

not mean that they are not entitled to respect."). In Twin City Milk Producers Ass'n v. MoNutt (C. C. A. 8th, 1941) 122 F. (2d) 564, 568, the court stated, "[The Administrator's] . . . specific construction of the regulation for purposes of this judicial review and the court's acceptance thereof would clearly, as a matter of due process, preclude any subsequent attempt on the part of the Administrator, without notice and further hearing under 21 U.S.C.A. $\$ 371$ (e), to enforce the regulation against animal feed, which petitioners purport to fear." (Italics supplied.) But the "specific construction" which the court thus rigidified had not been preceded by notice and hearing.

175 Veterans Administration, Readjustment Allowances for Veterans of World War II (Rev. June, 1945) Form 1386; and see Bartels v. Birmingham (1947) 332 U.S. 126, 132, concerning the warning on the title page of the Internal Revenue Bulletin ("The interpretive rulings on the Regulations ... do not have the force and effect of Treasury Decisions.").

1 i6 Barron Coop. Creanery v. Wickard, supra note 174; and see Bowles v. Seminole Rock Co. (1945) 325 U.S. 410, 418, n. 9; cf. Ten Broek, Interpretive Administrative Action and the Lawmaker's Will (1941) 20 ORE. I. Rev. 206, 244; Fitch Co. v. United States (1945) 323 U.S. 582, 586, n. 2.

177 Agencies sometimes try to avoid the inference by contemporaneous construction. 
Frequently, administrators make use of interpretations because they believe lawyers' language is not laymen's language. This belief underlies What Every Retailer Should Know About the General Maximum Price Regulation, Merchants and the Wage and Hour Law, ${ }^{178}$ Your Federal Income Tax, ${ }^{179}$ and hundreds of like popularizations. Popularized documents explain laws to the public and are planned by experts who know how to translate gobbledygook and legalese. Not all interpretations, however, are popularized; and contrasts between lawyers' and laymen's words do not account for the abstruse and legalistic interpretations agencies sponsor-sometimes for attorneys and other technicians, it is true, but frequently without regard to the talents of the audience. ${ }^{180}$ Furthermore, only the most obstinate legalists would contend that laws must be written in lawyers' words. Fortunately, the trend is the other way; and draftsmen are learning that laws can be most effective when addressed to the reader, and not just to his attorney or to judges. ${ }^{181}$ The result is that we now find laymen's words ${ }^{182}$ examples, ${ }^{183}$ charts, ${ }^{184}$ and even pictures ${ }^{185}$ in regulations themselves, and not merely in the interpretive documents.

If a document is phrased in words that can be legal, and if officials who can amend want the document to take effect as an amendment, courts cannot with prudence insist that it be labeled "amendment". ${ }^{186}$ There is surely no magic in the phrase "I amend". Nor are there in-

E.g., OPA Press Release 2814 [July 28, 1943] ("In making clear this limit on 'bighest price-lines' OPA did not change the meaning of the previous provision.").

178 U. S. Govt. Printing Office: 1941.

1 119 U. S. Govt. Printing Office: 1946.

180 E.g., Press Release A-9, issued by the Wage-Hour Division on Aug. 24, 1944 ("An employee will be considered to be paid on a 'salary basis' within the meaning of sections 541.1, 541.2 or 541.3 of Regulations, Part 541, if under lis employment agreement he regularly receives each pay period, on a. weekly, bi-weekly, semi-monthly, monthly or annual basis, a predetermined anount constituting all or part of his compensation, which amount is not subject to reduction because of variations in the number of hours worked or in the quantity or quality of the work performed during the pay period.").

181. See (1946) How Does Your Writing Read?, a pamphlet prepared by Dr. Rudolf Flesch and pubhished by the Civil Service Cominission; Cavers, The Simplification of Government Regulations (1947) 8 FED. B. A. J. 339; Beuscher, Law-Taught Attitudes and Consumer Rationing [1945] WIs. L. REv. 63, 70; and cf. note 6, supra.

182 E.g., MPR 580, supra note 11.

183 E.g., MPR 269 (the regulation involved in the Kraus chicken feet case) (1943)

S FED. REG. 13813, 13815.

184 E.g., RMPR 287, (1943) 8 FED. REG. 9122; cf. (1945) 10 ibid. 11480.

185 E.g., (1946) 11 ibid. $420,436$.

${ }^{180}$ See New England Telephone \& Telegrapll Co. v. United States (D. Mass. 1943)

53 Fed. Supp. 400, 412. 
herent trappings of style and sectionalization. We have not hesitated to give amendatory effect to "supplements", 187 "announcements", 188 "directions", ${ }^{180}$ "orders", ${ }_{100}$ "decisions", ${ }^{101}$ "revisions", ${ }_{102}$ "corrections", ${ }^{193}$ "permits", 194 "licenses", ${ }^{105}$ "rulings", ${ }^{106}$ and similar writings; and the addition of "interpretations" to this list can hardly be thought cataclysmic. Interpretations may be faulty, it is true; ${ }^{107}$ but judicial concern with fault need not extend farther for this kind of document than for the variety of others having a similar purpose. We must keep in mind that "courts are not charged with general guardianship against all potential mischief in the complicated tasks of government". 198

\section{The requirement of notice}

Nevertheless, before concluding that administrators can treat a document labeled "interpretation" as an amendment, we ought to be sure that people affected by the document have a chance (1) to learn of its existence, and (2) to examine its contents. Inter-office communications, opinions addressed to named persons, and other unpublicized rulings, no matter how authoritative, should not be law. ${ }^{100}$ To

187 E.g., 1945 C. C. C. Corn Bulletin 1, Supp. 1, (1946) 11 FED. REG. 60.

188 E.g., Supp. Announcement 8, (1945) 10 ibid. 14243.

189 E.g., General Direction No. 7, (1943) 8 ibid. 15530; Special Direction ODT 7, Revised -2, 8 ibid. 10446.

100 E.g., FCA Order 416, (1945) 10 ibid. 810; General Order 11, Reg. 7, 10 ibid. 12186; Special Order 22, 10 ibid. 12451; Exemption Order ODT 21-2A, (1943) 8 ibid. 7404.

101 E.g., T. D. 51231 , (1945) 10 ibid. 5350.

192 E.g., B.E. P. Q. 485, 14th Rev., (1945) 10 ibid. 15105; Rev. Supp. 6, (1945)

10 ibid. 5350; cf. 10 ibid. 4964.

193 E.g., (1945) 10 ibid. 5393 ; 10 ibid. at 13359.

194 E.g., General Permit ODT 17-22, (1943) 8 ibid. 7358.

105 E.g., General License No. 42, (1941) 6 ibid. 2907.

106 E.g., General Ruling No. 6, (1940) 5 ibid. 2807.

${ }^{107}$ Section 1 of MPR 1, (1.943) 8 ibid. 10116, advised that ceilings for rentals of new machine tools were fixed by RPS $67,(1942) 7$ ibid. 1202, as amended. In fact, RPS 67 made no provision for rentals. Cf. Conklin Pen. Co. v. Bowles (Em. Ct. 1945) 152 F. (2d) 764, 767; Lincoln Sav. Bank of Brooklyn v. Brown (Em. Ct. 1943) 137 F. (2d) $228,232$.

108 Federal Comm'n v. Pottsville Broadcasting Co. (1940) 309 U.S. 134, 146. Cf. Atty' Gen.'s Comm. on Admin. Proced., Final Report, SEN. Doc. No. 8, 77th Cong. 1st Sess. (1941) 115 ; note 161, supra.

199 See Southern Goods Corporation v. Bowles (C. C. A. 4th, 1946) 1.58 F. (2d) 587, 590; Fleming v. Van der Loo (App.D. C. 1947) 160 F. (2d) 906, 912; cf. Porter v. Leventhal (C. C. A. 2d, 1946) 160 F. (2d) 52, 59, n. 5; United States v. Birnbaum (S. D. N.Y. 1944) 55 Fed. Supp. 356, 358. But cf. 3 OPA, WEEKLY NEWs LETTER (Nov. 5, 1946) discussing Porter v. Royal Packing Co. (C. C. A. 8th, 1946) 157 F. (2d) 524 ("The court 
find out about amendments, most people watch their newspapers, trade periodicals, or commercial services; ${ }^{200}$ effective notice of an interpretation could best be assured by giving it this kind of publicity.

In lawsuits, however, we recognize but one notice rule; that is, regulations and their amendments must be published in the Federal Register. ${ }^{201}$ When, therefore, agencies have filed their interpretations with the Federal Register Division, they have complied with the only publication requirement that courts can rightly impose. In past years, the Federal Register has contained very few interpretations of regulations; ${ }^{202}$ but under the Administrative Procedure Act the volume is sure to increase. ${ }^{203}$ Federal Register publication should not free administrators from their practical responsibility, as public servants, to publicize rulings which change law-whether the rulings be phrased as interpretations or amendments. It does, on the other hand, discharge their legal responsibility. Hence, with Federal Register publication, agency interpretations that are authorized and duly authenticated should merit the same deference as formal amendments. ${ }^{204}$

apparently was not impressed with defendant's argument that the interpretations ... were merely inter-office communications which were not published in the Federal Register, because the court refers to two such interpretations in support of the conclusion reached by it.").

200 Cf. Brown v. Ciffo (E. D. N.Y. 1944) 1 CCH, PrICE Control $\llbracket 51,085$ ("The said defendant assumed the burden of showing that it acted in good faith and was ignorant of the contents of the Schedule, this I beheve to be erroneous, if Cutler, as he said he did, kept in touch with the daily metal papers.").

20149 STAT. (1935) 500, 502, 44 U.S.C. $\$ 307$; cf. $\$ 3(a)$ of the Administrative Procedure Act, supra note 3.

${ }^{202}$ E.g., Codification and Interpretation of E. O. 9128 (1942) 7 FED. REG. 3843; General Rulings under E. O. 8389, 31 Code FED. REgs. (Cum. Supp. 1944) 8843-8852; Digest of Interpretations of Regulations No. 8, (1939) 4 FED. REg. 1950; Interpretative Bulletin No. 1, (1945) 10 ibid. 5678 ; cf. 10 ibid. 5393.

203 Supra note 201. Section 3(a) calls for Federal Register publication of "interpretations formulated and adopted by the agency for the guidance of the public". Cf. Atty. Gen.'s Memo to Heads of Departments and Agencies (July 15, 1946) 8; and see (1946) 11 FEd. REg. 10918 (SEC interpretations).

204 See Markham v. Taylor (S. D. N.Y. 1947) 70 Fed. Supp. 202, 205 ("Even if there were any doubt on that subject, which $I$ do not entertain, this doubt was completely removed by the interpretive General Ruling No. 12 issued by the Secretary of the Treasury. on April 21, 1942 (7 F. R. 2913)."); cf. Berger and Bittker, Freezing Controls: The Effect of an Unlicensed Transaction (1947) 47 CoL. L. Rev. 398, 400, n. 17. Other cases in point are those dealing with declaratory statutes (i.e., duly authenticated statements of meaming by legislatures). See Legis. (1935) 49 HARv. L. REv. 137 (" . . . nnost declaratory statutes which have received judicial construction seem imconsistent with a bona fide attempt to interpret." [At 142, n. 16.] "[Nevertireless,] . . . if construed prospectively, they are upheld as amendments ...." [At 137.]). And compare Prudential Ins. Co. v. Benjamin (1946) 328 U.S. 408, 429, with Robertson v. Calif. (1946) 328 U. S. 440, 461. 


\section{When interpretations are not like amendments}

Agency interpretations that are not authorized and duly authenticated, or not published in the Federal Register, call for different treatment. Clearly, rulings that exceed agency authority, statutory or constitutional, should normally be held impotent. ${ }^{205}$ Officials cannot evade their enabling statutes, for example, or the Administrative Procedure Act, or the due process clause, by interpretations any more than by regulations or amendments.

One peculiar problem of authority, however, relates to interpretations that have retroactive effect. In general, administrators are not authorized to enforce retroactive amendments. ${ }^{206}$ If a ruling when stated as an amendment would be invalidly retroactive, an agency can hardly give it amendatory effect by stating it as an interpretation. Therefore, courts must often make the distinction noted in a recent case:

The question is not whether the ruling of the Administrator was valid prospectively as an administrative regulation. The question is whether it was so clear a translation of the terms of the original regulation as to render retroactively the prices of this retailer a violation of that regulation. ${ }^{207}$

Even so, the fact that retroactive interpretations cannot be binding does not make them useless. Courts that refuse to apply a ruling to conduct occurring before the date of its issuance can still hold it con-

205 Notes, Administrative Law: Retroactive Revision of Invalid Regulations (1947) 35 CaLIF. L. REv. 92 ; Prospective Operation of Decisions Holding Statutes Unconstitultional or Overruling Prior Decisions (1947) 60 HARv. L. REv. 437. Administrators most commonly exceed their authority to interpret regulations when they are construing "interpretive regulations". Since an interpretive regulation merely expresses conclusions by an agency as to the meaning of a statute (see Lee, Legislative and Interpretive Regulations (1940) 29 GEO. L. J. I), rulings interpreting the regulation must conform with the same legislative-intent test that governs the validity of the regulation. See Independent Petroleum Corporation v. Fly (C. C. A. 5th, 1944) 141 F. (2d) 189, 191; cf. Scofield v. Valley Pipe Line Co. (C. C. A. 5th, 1943) 138 F. (2d) 835, 837; United States v. Andolschek (C. C. A. 2d, 1944) 142 F. (2d) 503, 506.

206 Note (1947) 60 HARv. L. REv. 627.

207 Fleming v. Van der Loo (App. D. C. 1947) $160 \mathrm{~F}$. (2d) 906, 912; and see Porter v. Miller (C.C.A. 2d, 1946) 155 F. (2d) 88,90 (" ... we have not taken into account the Administrator's 'Statement of Consideration.' We do not decide whether these could have been apphed retroactively."). Cf. Note (1935) 49 HARv. L. REv. 137 (If declaratory statutes are construed to have retroactive effect, "they usually fail to surmount constitutional limitations . . . "); United States v. Smith (1932) 286 U. S. 6, 33 (" . . the court must give great weight to the Senate's present construction of its rules; but so far, at least, as that construction was arrived at subsequent to the events in controversy, we are not concluded by it."). 
trolling after that date. ${ }^{208}$ And all agency interpretations merit some weight, whether or not they are effective as amendments. The official interpretation of the executive order on foreign funds, for example, though issued after litigation as to the meaning of the order had begun, was' significant as showing what the people responsible for administering the order believed would best serve its aims. ${ }^{209}$ Courts have had a good deal of experience with the doctrine of "practical construction", which acknowledges administrators' talents in resolving interpretive doubts; and the relevance of that doctrine to our type of case is clear. ${ }^{210}$

The court of appeals for the second circuit has proposed that the respect accorded an agency interpretation depend on "the thoroughness evident in its consideration, the validity of its reasoning, its consistency with earlier and later pronouncements, and all of those factors which give it power to persuade, if lacking power to control". ${ }^{211}$ In this article, it has been suggested that agency interpretations do control when they are properly authenticated and published. ${ }^{212}$ When.

208 See In re The Borden Co. (Dept. Ag., 1947) 6 A. D. 511, 2 PIKE AND FISChER, AD. LAw, 13b, 31-45; Barksdale v. Fleming (C. C. A. Sth, 1947) 160 F. (2d) 494, 495 ("... in appellant's undisputed effort to comply with the regulation in the operation of his small business, he was justified in reading the regulation practically (until, of course, he should learn that the Administrator was insisting upon its literal reading and construction) ...."); and see Ammon v. Bowles (C. C. A. 8th, 1946) 154 F. (2d) 698, 701 ("I think a clarification of the Regulation rather than the imposition of damages ... was called for."). Cf. the discussion of Denning v. Fleming (C. C. A. 10th, 1947) $160 \mathrm{~F}$. (2d) 697 in 4 OPA, WEEkIX NEws LeTteR (March 17, 1947) 230 ("[The court] ... gave no weight to the interpretation, influenced perhaps by the fact that defendants discontinued the practice upon the issuance of the interpretation."). Courts should not, of course, insist that interpretations be phrased prospectively, since the administrator's "I mean" can easily connote "In the future I mean".

200 See Berger and Bittker, Freezing Controls: The Effects of an Unlicensed Transaction (1947) 47 CoL. L. REv. 398, 409; cf. Bowles v. Nu Way Laundry Co. (C. C. A. 10th, 1944) 144 F. (2d) 741,747, n. 3 ("This interpretation is not retroactive or binding here but it supports our interpretation of Regulation 165."). But $c f$. Porter v. Consolidated Badger Cooperative (C. C.A.7th, 1946) 157 F. (2d) 835, 836; and for a statutory analogy, see Viereck v. United States (1943) 318 U.S. 236, 246, n. 1.

210 Cf. Dickinson, Judicial Review of Administrative Determinations, A Summary and Evaluation (1941) 25 MINN. L. REv. 588, 601.

211 Walling v. Brooklyn Braid Co. (C. C. A. 2d, 1945) 152 F. (2d) 938, 940.

212 Many regulations cases raise questions that may seem interpretive but are treated as questions of fact. E.g., Walling v. St. Mary's Sewer Pipe Co. (W.D.Pa. 1944) 56 Fed. Supp. 345. When there is opportunity for a hearing, general experience teaches us that we can trust admimistrators to decide these questions fairly. See Brown, Fact and Lare in Judicial Reviers (1943) 56 HARv. L. Rev. 899. Ex parte decisions on questions of fact, however, are not final. See H. R. REP. No. 1980, 79th Cong., 2d Sess. 45 (" ... facts necessary to the determination of any relevant question of law must be de- 
they are not, the second circuit proposal may be as good a generalization as any. The words are borrowed from a Supreme Court opinion dealing with interpretation of statutes, ${ }^{213}$ and we are thus warned that the vagueness of the statutory cases may well attend the progress of the regulations cases. 214

When interpretations are not like amendments, they lack power to control. Our list of such interpretations has embraced rulings by officials other than those in charge of a regulation, rulings that are off-hand or qualified, rulings made without regard to amendatory procedures, and rulings not published in the Federal Register. Yet from this list we could cite instances where each type might be highly persuasive. Ordinarily, interpretations by one agency of another's regulations are of no consequence. When, however, the issuing agency announces that another agency has participated in the planning of a

termined of record somewhere and, if Congress has not provided that an agency shall do so, then the record must be made in court."). In cases where questions of fact are decided without benefit of agency hearing (e.g., Pyramid Motor Freight Corp. v. Ispass (1947) 330 U.S. 695, 707; and compare Collins v. Fleming (Em. Ct. 1947) 159 F. (2d) 426, with Ladner v. Bowles (Em. Ct. 1944) $142 \mathrm{~F}$. (2d) 566), problems of finality arise in reviewing determinations by juries (compare Fleming v. Ritcher (C. C. A. 2d, 1947) 159 F. (2d) 792, and United States v. Levy (C. C. A. 2d, 1943) 137 F. (2d) 778, with Barry v. Reading Co. (C. C. A.3d, 1944) 147 F. (2d) 129, and Ferguson v. Union Nat. Bank of Clarksburg, W. Va. (C.C.A.4th, 1942) 126 F. (2d) 753) and by trial judges (compare Bowles v. Patrick Lumber Co. (C.C.A. 9th, 1945) 151 F. (2d) 444, with Bartchy v. United States (1943) 319 U.S. 484; and see De Fremery \& Co. v. United States (Ct. Customs and Pat. App. 1943) 138 F. (2d) 161).

Also see Standard Oil Co. v. United States (1931) 283 U.S. 235, 238, where the Court noted, "The case before the Commission [ICC] did not, as contended, involve inerely the construction of the written words employed in a rate tariff-a siniple question of law-but required consideration of matters of fact and the application of expert knowledge for the ascertainment of the technical meaning of the words and a correct appreciation of a variety of incidents affecting their use." Accordingly, "There heing nothing to suggest that the Commission acted arhitrarily or without evidence to support its conclusions, or that it transcended its constitutional or statutory powers, . . . the order of the Commission was not susceptible of review by the courts." Ibid. at 240 . Accord: Schafer v. Helvering (1936) 299 U. S. 171; Morgan Stanley \& Co. v. Securities Exchange Com'n (C. C. A. 2d, 1942) 126 F. (2d) 325, 331; cf. Note (1947) 60 Harv. L. REv. 448. Similar rules should govern when regulations, by their ternis, make administrative action discretionary rather than interpretive. E.g., 33 CODE FED. REGs. (1938) $\$ 303.4$ ("The regulations in this part will be enforced subject to the discretion of the United States officer in charge so as not to obstruct unnecessarily the navigation of vessels of the merchant marine."); CoDE FED. REGS. (Supp. 1945) § 8320.1(b)(1); cf. Markall v. Bowles (N. D. Calif. 1944) 58 Fed. Supp. 463.

213 Skidmore v. Swift \& Co. (1944) 323 U.S. 134, 140.

214 See note 156, supra; cf. Frankfurter, Some Reflections on the Reading of Statutes (1947) 47 CoL. L. REv. 527, 530 ("Though my business throughout most of my professional life has been with statutes, I come to you empty-handed. I bring no answers."). 
regulation, and recommends that all inquiries be addressed to the other agency, interpretations by the latter have a weight at least equal to that given rulings of the former. ${ }^{215}$ Similarly, if the question at issue pertains, say, to the ladies' garment industry, a ruling by a Manhattan field office may reflect the same information and expertness that courts would have assumed, had it been issued from Washington. When rulings are Washington-sponsored, a court should realize that underlings in a branch or division often merit respect that cannot realistically depend on their use of the head administrator as front man. ${ }^{216}$ Even the off-hand rulings do not lack persuasion if they are later exposed to intra-agency review, and rulings that were qualified when issued may achieve cogency if they stand the test of long-continued administration. ${ }^{217}$

Should interpretations be persuasive if they differ from earlier agency rulings? Perhaps not, if the inconsistency is caused by lack of forethought or an eagerness to get results that fit immediate aims.

215 E.g., OPA Press Release PM-3264 (May 12, 1942); cf. (1942) 3 F.P.C. 115, n. 15, 257, n. 4 (FPC interprets ICC and SEC regulations). On occasion, the issuing agency borrows concepts defined by other agencies, or by private groups. E.g., Office of Censorship, Communications Ruling No. 1, 1942, $1 \mathrm{CCH}$, WAR LAw If 9025 (" . . the term 'United States' and the term 'person' shall have the meaning prescribed in Executive Order No. 8389 , as amended, and the term 'enemy national' shall have the meaning prescribed in General Ruling No. 11, issued by the Secretary of the Treasury . . . ."); Appendix B of MPR 540, (1944) 9 FED. REG. 12682 (automohile models described by reference to manufacturers' trade names); and $c f$. the discussion of Bowles v. Ferrara (D. Del. 1946) 66 Fed. Supp. 575, in 3 OPA, WeEkLY News LeTter (March 25, 1946) 216, 217 (The fact that Data Book for Dealers in Used Commercial Vehicles had heen incorporated in Appendix C of MPR 34I "was apparently overlooked by the court".).

Executive orders present special problems, since in most cases they are neither drafted nor administered by the Executive Office of the President. See 29 CODE FED. REGs. (Supp. 1944) § 1202.1 (FEPC interprets executive order on fair employment practices); General Ruling No. 1, 31 Code FEd. Regs. (Cum. Supp. 1944) p. 8843 (In view of advice from Secretary of State, "the Treasury Department construes the term 'Denmark' as used in the above-inentioned Executive Order and regulations as not applying to Iceland."); Hitchcock v. United States ex rel. Bigboy, supra note 163; and cf. E. O. 9301, 3 CODE FED. REGS. (Cum. Supp. 1943) p. 1253.

216 Cf. Winslow Bros. \&c., Co. v. Hillsborough Mills (1946) 319 Mass. 137, 143, 65 N.E. (2d) 1, 4. As to whether the arguments of enforcement attorneys should he regarded as "official" interpretations, see Bowles v. Dairymen's League Co-op. Ass'n (S.D.N.Y. 1945) 61 Fed. Supp. 358; Levers v. Anderson, supra note 75 ; and cf. Superior Packing Co. v. Porter (C. C. A. 8th, 1946) 156 F. (2d) 193, 195; Porter v. Consolidated Badger Cooperative (C. C.A.7th, 1946) 157 F. (2d) 835, 836; Goodman v. Bowles (Em. Ct. 1943) 138 F. (2d) 917, 919; Umited States v. Silk (1947) 331 U.S. 704, 715, n. 9 ; Lypp v. United States (C. C. A. 6th, 1947) 159 F. (2d) 353, 355.

217 In most instances, the reason for qualifying rulings is not a fear that courts may adopt them but a fear that courts may block their revision. Cf. note 219, infra. 
Further, the fact that rulings have been inconsistent may call for protection of persons who relied upon an interpretation differing from the one now sponsored by the agency. ${ }^{218}$ Nevertheless, we must let administrators cure errors and profit from experience; and judges can hardly disregard an interpretation on the sole ground that an earlier ruling was inconsistent. Judges must recognize, too, that regulations-like statutes-have no Platonic or ideal meaning and, accordingly, that revised rulings do not necessarily relate back and render earlier rulings nugatory. ${ }^{219}$

In cases where agency interpretations lack power to control (and also in cases where courts are unaided by agency interpretations), the statutory precedents may well be our best guides. The essential rule, perhaps, is not to violate plain words-for whatever our bent toward administrative persuasion, we cannot ordinarily grant that "white" means "black", or that "elephants" include "camels". ${ }^{220}$ Justice Frankfurter has reminded us that interpretive problems arise only when there is a "fair contest between two readings"-not when a particular reading is sponsored by "literary perversity or jaundiced partisanship". ${ }^{221}$ The borderlines of plain meaning are litigious, true, but we can concede that on occasion administrators can be perverse and partisan. ${ }^{222}$

$218 C f$. Fleming v. Myers (C. C. A. 9th, 1947) 159 F. (2d) 210.

219 See In re St. Lawrence County Cooperative Dairies, Inc. (Dept. Ag., 1945) 2 Pike and Fischer, Ad. LAw, 34f. 31-6; of. United States Gypsum Co. v. Brown (Em. Ct. 1943) 137 F. (2d) 803 ; Gt. Northern Ry. v. Sunburst Co. (1932) 287 U. S. 358, 364; note 208, supra. Contra: In re Firestone Tire \& Rubber Co. (N. W. L. B., Sept. 1, 1943) 5 PIke ANd Fischer, Ad. LAw, Dec. Note No. 633; and see F. Uri \& Co. v Bowles (C. C. A. 9th, 1945) 152 F. (2d) 713, 718; of. Superior Packing Co. v. Porter (C.C. A. 8th, 1946) 156 F. (2d) 193, 195. As against particular persons, agencies may be estopped from revising interpretations retroactively. Cf. Bowles v. Indianapolis (C. C. A. 7th, 1945) 150 F. (2d) 597, 601; Coombe v. United States (App.D. C. 1925) 3 F. (2d) 714, 716. The problem of determining whether interpretations bind agencies must, however, be distinguished from the problem of determining whether they bind the public. Cf. Norem, The "Official Interpretation" of Administrative Regulations (1947) 32 Iowa L. REv. 697.

$220 \mathrm{Cf}$. note 24, supra. In contrast to agency interpretations of regulations, declaratory statutes seem to reflect a "legislative faithlessness to the expression of actual intention". Accordingly, in cases where they cannot stand as amendments, "it is not surprising that courts have paid only lip-service to declaratory acts as aids to construction, employing them to reinforce rather than to be found conclusions". (1935) 49 HARv. L. REv. $137,142$.

221 Op. cit. sulpra note 214 , at 527.

222 Cf. Armour \& Co. of Delaware v. Brown (Em. Ct. 1943) 137 F. (2d) 233, 240; Ammon v. Bowles (C. C. A. 8th, 1946) 154 F. (2d) 698, 700 ("Regulations such as those here involved are intended for the guidance of ordinary business men and inanufacturers, who may, we thimk, justifiably assume that the regulations mean what their language, 
And now, a final question: At what point in this sifting of formality and persuasion do we consider "administrative intent"? The intent of a regulation does not concern us when we determine the validity of its amendments. Accordingly, when an interpretation is like an amendment, claims that it violates a meaning or purpose originally assigned to the regulation are irrelevant. When an interpretation is not like an amendment, we must consider the original intent of the regulation. Yet at the same time we can concede that interpretations often serve as the best evidence of the intent. The man we call "administrator" usually has being and personality-unlike the multimouthed, two-headed abstraction we label "legislature". When we deal with regulations, agency rulings are frequently much more direct and useful, in examining meaning and purpose, than the committee reports or Congressional debates we use in dealing with statutes. ${ }^{223}$

In the main, "admimistrative intent" is a concept which courts are certain to mold in imagery of "legislative intent". Since judges and scholars are not in agreement as to the proper place of intent in statutory construction, we can hardly expect the regulations parallel to progress more rationally. ${ }^{24}$ As noted above, however, the regulations cases are not corrupted by a plain meaning rule. This fact suggests that analysis of the statutory materials might help us to shun other pitfalls. If we could agree that, at their best, maxims do no more than "invest with the appropriate symbolic uniform a conclusion that should have been quite as respectable in the ordinary civilian clothes of sober. common sense", 225 we might avoid some of the grief that maxims cause, at their worst. If we could agree that overindulgent use of extrinsic aids often distorts intent, we might avoid the overdose of

taken and understood in its usual sense, imports."). It must be remembered, too, that administrative error can have motivations other than "reform" and "Iust for power". E.g., see Note, Government Building Curbs [AApril 6, 1946] 6 BREAd AND BUTTER 2: "Loose administration along typical OPA lines could easily nullify a large part of the [Veterans' Emergency Housing] order, unless veterans and their organizations are on the alert to prevent any sabotage by 'interpretation.' "Cf. UAW Attacks OPA on Car Price Rises, in the New York Times, May 2, 1946, at 14 (union challenges agency interpretation of executive order); Emlen v. Social Security Board (E.D. Pa. 1944) 54 Fed. Supp. 498, 499 (SSB denial of insurance benefits) ; Schwartz v. Trajer Realty Corporation (S. D. N.Y. 1944) 56 Fed. Supp. 930, 932 (OPA ruling favoring landlords).

223 Cf. notes 26-41, supra; note 226, infra.

224 Compare SutherLand, op. cit. supra note 4, at 314-326, with Radin, $A$ Short Way With Statutes (1942) 56 HARv. L. REv. 388; Eisenstein, op. cit. supra note 156, at 509; and Frankfurter, op. cit. supra note 214, at 537.

225 Radin, op. cit. supra note 224, at 423. 
inference that lately has characterized so much statutory interpretation..$^{220}$

The rules are not yet formulated, and their development will be wearisome. It will not be enough to advise judges that regulations should be construed so as to "suppress the mischief, and advance the remedy, and ... suppress subtle inventions and evasions for the continuance of the mischief". ${ }^{227}$ This advice can, though, serve as a starter. Courts are not likely to err fundamentally if they proceed with awareness that the purpose in view is for consideration, always.

228 Cf. the opinions in Jewell Ridge Corp. v. Local (1945) 325 U.S. 161 ; and see Eisenstein, The Clifford Regulations and the Heavenly City of Legislative Intention (1947) 2 Tax L. REv. 327, 336. Justice Jackson is reported to have confessed that the Supreme Court has "found itself spending much of its time in psychoanalysis of Congress". San Francisco Chronicle, Jan. 15, 1947, at 1. Cf. Frankfurter, op. cit. supra note 214 , at 539 ("We are not concerned with anything subjective. We do not delve into the mind of legislators or their draftsmen, or committee members."); ibid. at 543 ("Spurious use of legislative history must not swallow the legislation so as to give point to the quip that only when legislative history is doubtful do you go to the statute.").

To illustrate the range of extrinsic aids that may be relevant in interpreting regulations, see OPA, WEEKIY NEws LeTTER (Oct. 9, 1944) 4 ("economic background"); In re Grandview Dairy, Inc. (Dept. Ag., May 8, 1944) 3 Pike ANd Fischer, Ap. Law, 48f. 712-14, 25 (failure to adopt proposal forbidding certain action held not duc to any intention to permit such action); Bowles v. Munsingwear (D. Minn. 1945) 63 Fed. Supp. 933 (testimony of draftsman). And cf. Pearson v. Walling (C. C. A. 8th, 1943) 138 F. (2d) 655; Hawkins and Wallace, Antitrust During National Entergencies-Executive Immunity (1945) 24 Tex L. REv. 51, 67.

227 Cf. Sutherrand, op. cit. supra note 4, at 280 , where this classic quotation from Heydon's Case (1584) 76 Eng. Rep. 637, also appears. 